\title{
SET-BACK DISTANCES TO PROTECT NESTING AND ROOSTING SEABIRDS OFF VANCOUVER ISLAND FROM BOAT DISTURBANCE
}

\author{
By \\ TRUDY ANNE CHATWIN \\ B.Sc., University of Victoria, 1981 \\ A thesis submitted in partial fulfillment of the requirements for the degree of \\ MASTER OF SCIENCE \\ In \\ ENVIRONMENT AND MANAGEMENT
}

We accept this thesis as conforming to the required standard

Michael Stalberg, Thesis Sponsor

Dr. Alan Burger, Thesis Supervisor, University of Victoria

Dr. Lenore Newman, Masters of Environment and Management Program Head, School of Environment and Sustainability

Dr. Tony Boydell, Director, School of Environment and Sustainability

ROYAL ROADS UNIVERSITY

February 2010

(C) Trudy Chatwin, 2010 


\section{Acknowledgments}

This project had many supporters from the idea stage, to executing the field studies, through the rough seas of data analysis, writing and submission. I wish to thank them all.

The Ministry of Environment and the Habitat Conservation Trust Foundation provided funding for this work and have been a wonderful support. Liz Hammond-Kaarremaa and family have kept me going forward throughout and provided kind and gracious support with everything from computers to accommodation. Ruth Joy patiently guided me through the statistical analysis and is a wonderful friend. I was very fortunate to have Dr. Alan Burger as my supervisor as he provided a wealth of knowledge about seabirds, encouragement and insightful, timely and constructive review of this thesis.

Pete Clarkson, Francis Bruhwiler, Peter Pauwels, Gary Horncastle, Mike Rody and Mark Kaaremaa ably navigated the boats and carried the kayak to conduct the field trials. There were many able field assistants including Monica Mather, Jenna Cragg, Anna Gerrard, Anne Tuonimen, Julia Chatwin, Karen Morrison, Erica McClaren, Eric Demers, Liz HammondKaarremaa, Bill Pennell and Robin Hood.

Many friends, colleagues and family have been patient with this process and without them I wouldn't have finished. Notable among these are my partner, Ian and my mutt, Tierra 


\begin{abstract}
In order to set guidelines that promote responsible wildlife viewing, I quantified the effects of boat-based disturbance to seabirds off Vancouver Island. Field trials recorded the approach distance at which roosting and nesting birds responded to either a motor boat or a kayak. Probability of agitation response was used to evaluate disturbance. At a distance of $40 \mathrm{~m}$ nesting Double-crested Cormorants, Pelagic Cormorants, Glaucous-winged Gulls, Pigeon Guillemots and Black Oystercatchers had less than an $8 \%$ chance of being agitated with either a kayak or motorboat approach. Roosting birds had longer response distances. Harlequin Ducks were particularly sensitive with a $25 \%$ probability of agitation at distances less than $50 \mathrm{~m}$. Agitation distances were reduced by habituation to boat traffic. A set-back guideline of $50 \mathrm{~m}$ would protect most nest and roost sites in the study area while allowing viewers to appreciate seabirds. Some sensitive sites would require $70 \mathrm{~m}$ set-backs.
\end{abstract}




\section{Table of Contents}

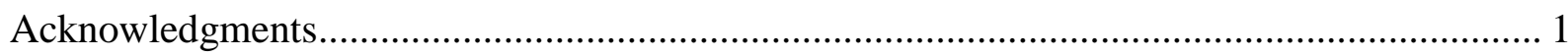

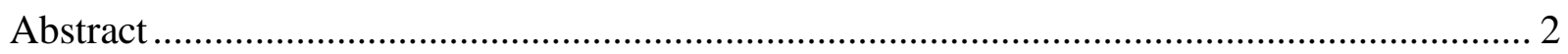

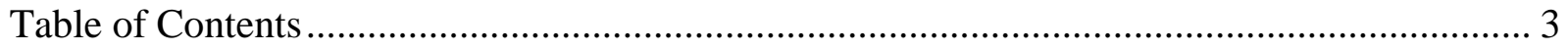

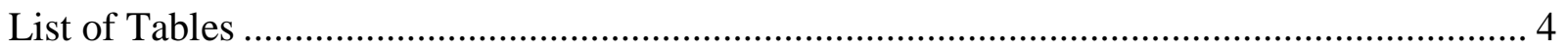

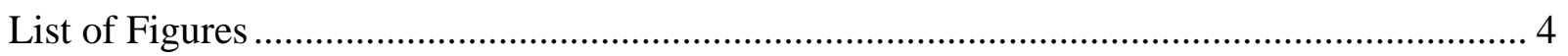

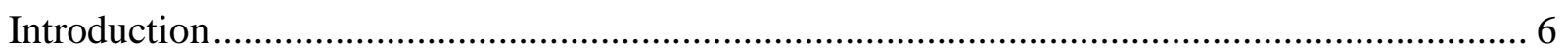

Impacts of boating disturbance to seabirds ........................................................... 7

The role of wildlife viewing in promoting conservation values ...................................... 8

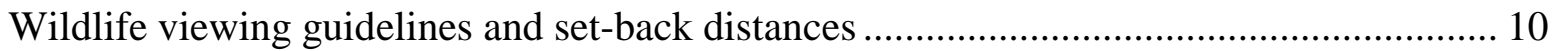

This study in relation to bird disturbance research ................................................. 11

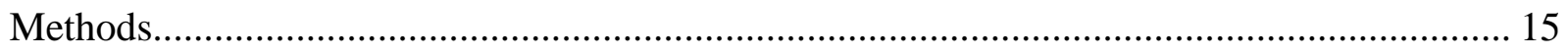

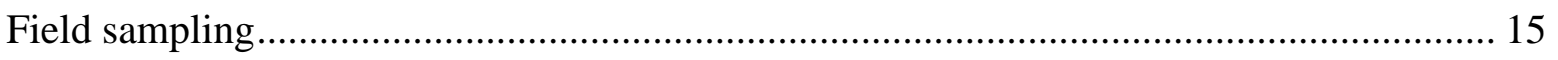

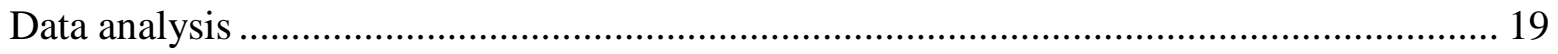

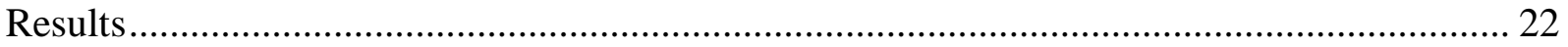

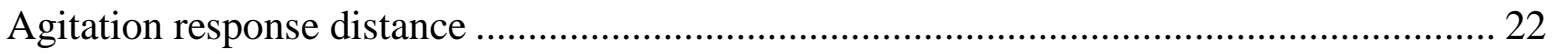

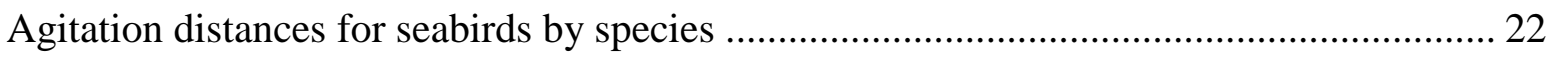

Agitation distances for nesting seabirds ................................................................ 23

Agitation distances tested with survival analysis....................................................... 25

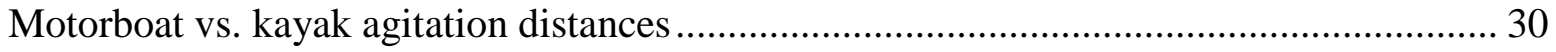

Effects of boat traffic on agitation distance .......................................................... 31

Seasonal timing of disturbance and agitation distance for nesting birds .......................... 34

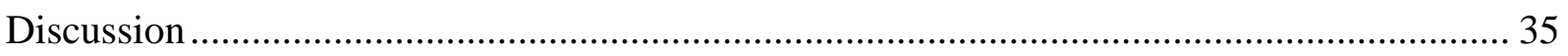

Factors affecting disturbance response ............................................................. 35

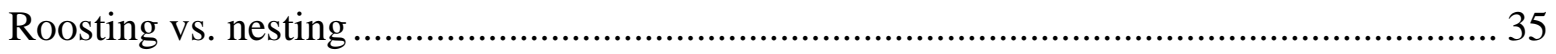

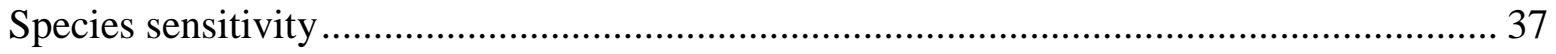

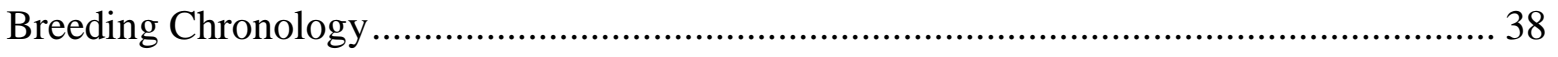




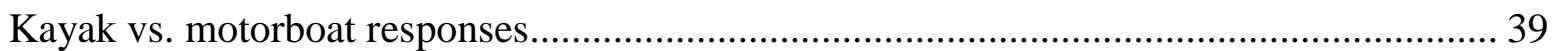

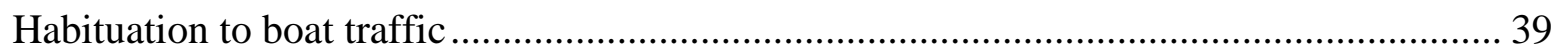

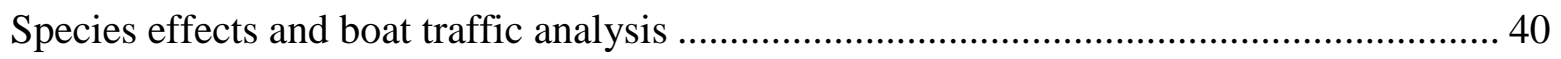

Management recommendations for set-backs for seabird nest and roost sites .................... 42

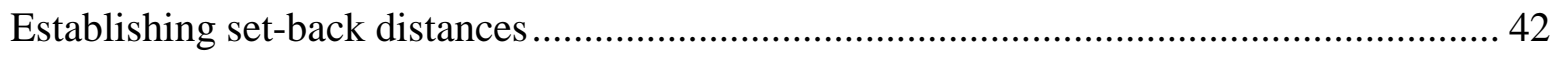

Implementation of seabird viewing guidelines ..................................................................... 45

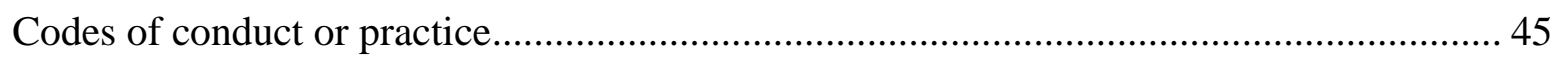

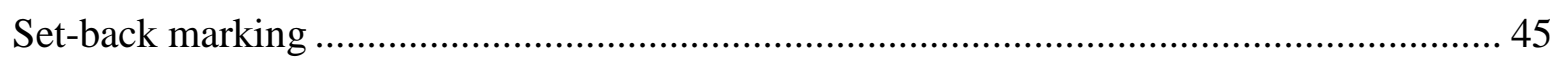

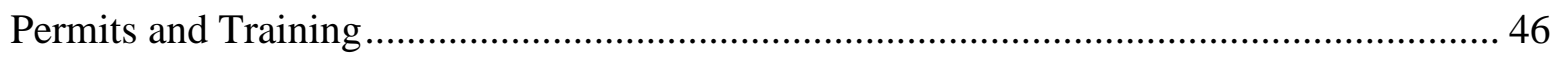

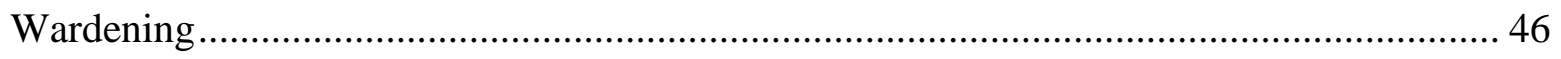

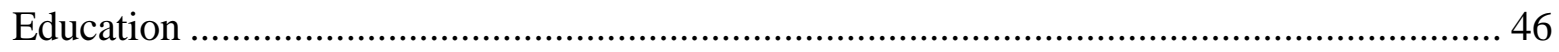

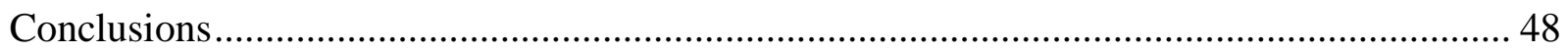

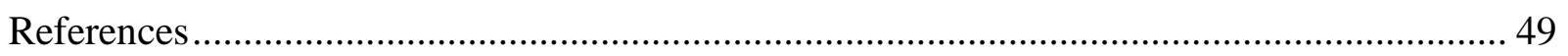

Appendix 1 Data Collection Form .................................................................................. 58

\section{List of Tables}

Table 1. Probability of agitation for nesting and roosting seabirds.......................................... 29

Table 2 Probability of agitation for kayaks and motorboats....................................................... 31

Table 3. Number of tests of various seabird species at High, Medium and Low boat traffic sites.

Table 4. Probability of seabirds agitated at various distances at High, Medium and Low Boat traffic sites.

Table 5 Probability of nesting seabirds being agitated at 50,40 and $30 \mathrm{~m}$ approach distances during early, mid and late breeding season................................................................................ 34

Table 6. Boating guidelines for viewing roosting and nesting seabirds ..................................... 44

\section{List of Figures}

Figure 1 Study areas on Vancouver Island showing major seabird nest and roost sites. ............. 16

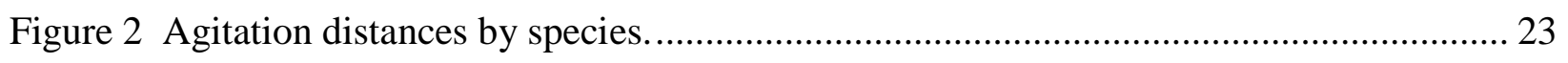


Figure 3. Boxplots for agitation of nesting seabirds ........................................................ 24

Figure 4 Boxplots of agitation distance for roosting seabirds. ............................................ 25

Figure 5. Plot of the proportions of nesting seabirds agitated at varying distances................... 27

Figure 6 Plot of the proportions of roosting seabirds agitated at varying distances. ................. 28

Figure 7. Plot of birds agitated by motorboat and kayaks. ................................................. 30

Figure 8. Seabird agitation at High, Low and Medium boat traffic........................................ 33 


\section{Introduction}

Environmental impacts to natural areas and wildlife through recreation and tourism include overcrowding, overdevelopment, unregulated recreation, pollution and disturbance. Wildlife disturbance by people, vehicles and boats is a serious issue that park and wildlife managers routinely face (Langston et al., 2007; Newsome et al., 2002; Roe et al., 1997), yet scientific information to assess the level of threat and the effectiveness of mitigation measures is often not available.

Seabird breeding and roosting sites are eco-tourist destinations in many parts of the world, such as the Antarctic (Wilson et al., 1991), Baja (Anderson \& Keith, 1980), Galapagos Islands (Burger \& Gochfeld, 1993), and Great Barrier Reef (Great Barrier Reef Marine Park Authority, 1997). On Vancouver Island, British Columbia, eco-tourism boating excursions from Ucluelet, Tofino and Victoria regularly visit Cleland and Great Chain Island Ecological Reserves, Mandarte Island, Gulf Islands and Pacific Rim National Parks. Recreational boaters, fishermen and sea kayakers visit offshore islets, reefs and coastal areas which support roosting and nesting seabirds. Some of the species nesting on Vancouver Island, including Doublecrested Cormorant (Phalacrocorax auritus), Brandt's Cormorant (Phalacrocorax penicillatus) and Common Murre (Uria aalge), are listed provincially as species-at-risk (B.C. Conservation Data Centre, 2010) and Pelagic Cormorants (Phalacrocorax pelagicus) are declining (Chatwin et al., 2002). As approach distances for seabirds vary among species and sites, observations on critical approach distances at a site are necessary before management prescriptions are formulated (Burger et al., 2010; Carney \& Sydeman, 1999; Great Barrier Reef Marine Park 
Authority, 1997). It is therefore important to provide scientifically-based information to support boating guidelines for conservation of seabirds on Vancouver Island.

The objectives of this study were to:

- test, with a standardized approach, the distance at which roosting and surface-nesting seabirds display a disturbance response to boats;

- determine if the variables of nesting vs. roosting, species, boat type, boat traffic (as a measure of habituation), and seasonal timing have an effect on the disturbance response;

- make recommendations for set-back distance guidelines that will protect seabirds from boating disturbance while allowing viewers to appreciate the birds.

\section{Impacts of boating disturbance to seabirds}

Disturbances through boat approaches that are too close are often cited as a major threat to birds (Anderson \& Keith, 1980; Manuwal, 1978; Vennesland \& Butler, 2004) and are known to disrupt nesting, care of young, feeding, and resting (Burger et al., 1995; Frid \& Dill, 2002). Disturbance effects vary from temporary displacement of individuals, to a population effect when a nesting colony abandons a site that is continually disturbed. The success of seabird breeding is related to variation in the abundance of prey, the capacity of birds to obtain food to feed their chicks and predation by other animals. Disturbed birds that flush from nests can lose their eggs or chicks due to stampeding, thermal stress, predation by crows or gulls, infanticide or nest desertion (Burger, 1981). These effects can cause declines in reproductive success and birds may shift the breeding location (such as albatross colonies in the Galapagos Islands and Taiaroa Head, New Zealand (Roe et al., 1997), delay breeding or desert a colony altogether (Great 
Barrier Reef Marine Park Authority, 1997; Nisbet, 2000). Manuwal (1978) noted that when Double-crested Cormorants are disturbed they frequently step on eggs or knock them out of the nest. Young cormorants will run from the nest, fall off cliffs or get killed by circling gulls.

Behavioral researchers Frid and Dill (2002) equate human disturbance to a predation risk, whereby animals change their activity to avoid potential predation. There is an energetic cost to stress caused by disturbance for both roosting and nesting birds. The stress induced by direct disturbance starts with alertness, followed by agitation, then escape (flight or, in the case of molting waterfowl, swimming away). These reactions are frequently associated with physiological responses to hormonal changes and result in increased heart and respiration rates, elevated blood sugar and a rise in body temperature (Walker et al., 2006; Weimerskirch et al., 2002)Responses are most intense when birds are nesting or caring for young. Penguins have been shown to have increased stomach temperatures and heart rate in response to close human presence, even though they did not move off eggs (Regal \& Putz, 1997). As conservation of energy is critical, the additional energy expenditure could result in reduced vigour and breeding success. Roosting birds (i.e., birds resting on land between foraging bouts) could be selecting specific locations to rest, preen feathers, engage in courtship or remain near good feeding sites. Non-breeding birds also are present at nesting colonies during breeding season. Displacement from roost-sites causes interruption of feeding patterns, energetic loss and birds may then locate to less optimal roost sites.

\section{The role of wildlife viewing in promoting conservation values}

Nature tourism is particularly dependent on the quality of the resource. It is therefore important to sustain the resources (seabirds in this case) that wildlife viewers are observing. 
Murphy (1994) defines sustainable tourism as "management of all resources in such a way that we can fulfill economic, social and aesthetic needs while maintaining ecological processes, biological diversity and life-support systems". Sustainable tourism will increase support for and the value attributed to natural areas and wildlife (Newsome et al., 2002). Wildlife viewing is an integral part of visitor experience in parks and natural areas. Ecosystem management in these areas requires understanding and consideration of the social dimension of wildlife viewing. Ecotourism, including access to wildlife, is critical for generating public support for wildlife conservation (Gill, 2007; Newsome et al., 2002) and is important for generating economic activity. Nature-related activities in Canada generated \$11 billion for 1996 (Gray et al., 2003) and wildlife watching generated $\$ 45.7$ billion in 2006 in the United States (Leonard, 2006). Wildlife viewing builds public and political support and justification for conservation (Tisdell \& Wilson, 2000, 2006). Well-informed viewers, guides, fishermen and recreational boaters bring knowledge, ideas and resources to help manage and sustain wildlife and natural areas. Rollins et al. (2009) discuss the effects of tourism on environmental conservation in parks and point out that the negative environmental impacts from tourists have received much attention due to a more recent shift in park management focused on environmental protection. Many negative impacts can be reduced or eliminated through good management and setting of reasonable standards. Ecotourism provides many positive benefits such as promoting stewardship and education. Agencies have a role in setting standards when granting permits to eco-tour operators which in turn provides an opportunity to ensure that resources are protected while enriching visitor experience. Well-managed ecotourism, which involves setting scientifically-based guidelines, consultation with stakeholders, and interpretation, can be used to reduce negative 
impacts on the environment, minimize effects on wildlife, decrease enforcement problems and encourage visitors to adhere to selected locations and set-back distances.

\section{Wildlife viewing guidelines and set-back distances}

Wildlife viewing distance guidelines have been well established for species which are focal tourist attractions, such as grizzly bears (Peek et al., 1987) and whales (Fisheries and Oceans Canada, 2007). Despite consequences of disturbance to nesting seabirds, guidelines for viewing seabirds in British Columbia have either not been established or are based on regulations developed for viewing marine mammals. For example, in Gulf Islands National Park Reserve, areas containing small islets with seabirds are included in a Special Preservation Zone with a 100 $\mathrm{m}$ buffer (Parks Canada, 2006). These distances were based on being consistent with regulations for boaters when approaching Killer Whales (Todd Golumbia, Parks Canada; personal communication). Pacific Rim National Park Reserve Wildlife Viewing Guidelines (Parks Canada, 2003) recommend: slowing "down to 5 knots; no-wake speed at $250 \mathrm{~m}$; vessel behavior based on the most sensitive species; approach at an indirect angle; moving closer gradually; not going ashore; limiting time in the "close-viewing zone" to 15 minutes; giving sea caves and other areas with cliff-nesting cormorants and murres a $50 \mathrm{~m}$ buffer; and avoiding sensitive areas like nesting sites and colonies". Site-specific guidelines of $100 \mathrm{~m}$ set-back were provided by Parks Canada (2003) for Gowland Rocks, Sea Lion Rocks, White Island and Seabird Rocks off Vancouver Island. Although Cleland Island is managed by the Province of BC, the Parks Canada guidelines recommend a $100 \mathrm{~m}$ set-back (with the exception of the Gap) for Cleland Island Ecological Reserve. The Canadian Wildlife Service (2003) drafted guidelines for visiting seabird colonies in Canada and for 'on water' they recommend maintaining "a minimum distance of at least $100 \mathrm{~m}$ from all areas of the island or colony occupied by seabirds, unless 
otherwise authorized by permit." The Seabird Survival Program (a joint program of the BC Federation of Naturalists, Bird Studies Canada and scientific experts) published a Seabird Survival brochure (Important Bird Areas of Canada \& Federation of BC Naturalists, 2006) that recommended a $100 \mathrm{~m}$ minimum distance for viewing seabird nest-sites from boats. These distances were set conservatively (i.e., far) as there was little information to make an informed set-back distance. Boaters seldom adhere to these guidelines (Ron Quilter, BC Parks; Pete Clarkson, Parks Canada; Peter Pauwels, BC Conservation Officer; personal communications, 2005) as they are likely set too far for boaters to see the birds. Set-back distances based on actual disturbance effects and scientific data will assist both managers and eco-tourism operators ensure that wildlife viewing is both an enriching and ecologically sustainable activity. The goal of my study was therefore to recommend scientifically-based set-back distances which would minimize disturbance to birds while allowing boaters to enjoy viewing seabirds.

\section{This study in relation to bird disturbance research}

Several authors have reviewed studies of the effect of human-caused disturbance to birds and have discussed implications and recommendations for future research which included designing measures to reduce human impact, the effect of habituation, the relationship between predation and disturbance, planning to minimize the impact of disturbance and testing of mitigation measures to reduce disturbance (Carney \& Sydeman, 1999; Hill et al., 1997; Hockin et al., 1992; Nisbet, 2000; Sutherland, 2007). Carney and Sydeman (1999), in particular, recommended further study of the "distance waterbirds are first perturbed by human activity (approach/agitation distance)". 
Using criteria of ease of use, precision in quantifying impact, accuracy in predicting population viability and repeatability, Tarlow and Blumstein (2007) evaluated methods to quantify disturbance stressors that negatively impact wildlife, and concluded that no single method was optimal. They found that experiments measuring flight initiation distance (sometimes written as FID) were the easiest method to use and were ranked medium in quantifying impact and repeatability, but ranked low on their ability to predict population viability. Some studies measured heart-rate (Holmes et al., 2005; Wilson et al., 1991), body temperature (Regal \& Putz, 1997) or corticosteroid stress hormone levels (Fowler, 1999; Walker et al., 2006) in birds, which all evaluated the non-visible effects of stress before a bird takes flight. This type of invasive study was not considered practical for the purposes of recommending set-back guidelines.

Most of the experimentally-based studies that measured approach distance thresholds used mean flight initiation distances to determine buffers or set-back distances (Gill, 2007; Rodgers \& Schwikert, 2002; Rodgers \& Smith, 1995). The studies conducted by Rodgers and colleagues took mean flight distance, added 1.65 standard deviations and then added up to $40 \mathrm{~m}$ to ensure safety for birds. They recommended buffer zones of $180 \mathrm{~m}$ for wading birds, $140 \mathrm{~m}$ for gulls and terns, $150 \mathrm{~m}$ for Ospreys (Pandion haliaetus) and $110 \mathrm{~m}$ for plovers and sandpipers that were foraging and loafing in Florida. Erwin (1989) found that that tern colonies on the South Carolina coast could be approached from 50 to $150 \mathrm{~m}$ before first flight and suggested a buffer of $200 \mathrm{~m}$. From a management perspective, using mean flight initiation distances to set buffers implies that a certain percentage of birds will fly and be disturbed, although the addition of the standard deviation distance and the $40 \mathrm{~m}$ means that the buffer distance is very conservative. For example, for Osprey the average flight distance was $49.5 \mathrm{~m}$ but the 
recommended buffer distance was $150 \mathrm{~m}$. Hentze (2006) observed the mean distances that Marbled Murrelets (Brachyramphus marmoratus), Common Murres, Rhinoceros Auklets (Cerorhinca monocerata) and Pelagic Cormorants dived or flushed in response to a boat on the waters off Pacific Rim National Park, BC and concluded conservatively that buffer distances of $150 \mathrm{~m}$ would eliminate most boat disturbance effects, and a $1 \mathrm{~km}$ exclusion zone parallel to shore would eliminate all effects. Bellefleur et al. (2009) evaluated the minimum distance that Marbled Murrelets on the water off Pacific Rim National Park Reserve exhibited a disturbance response in response to boat approach. Their study evaluated time of day, seasonality, boat type, boat density and boat speed effects on approach distance. Their study used survival probability analysis to incorporate non-flush distance data and focused on the distance that 25\% of Marbled Murrelets reacted. Ronconi and Cassady St. Clair (2002) observed flushing behavior of foraging Black Guillemots (Cepphus grylle) in the Bay of Fundy and analyzed the effects foraging distance from shore, size, speed and approach distance of boats to probability of flushing. They suggested that a set-back distance of $600 \mathrm{~m}$ from shore and maximum boat speed limit of 25 $\mathrm{km} / \mathrm{hr}$ would reduce flushing by guillemots.

Burger et al. (2010) measured both distance to first response (distance that birds allow a human to approach without demonstrating any behavioral effects) and distance to first flight to determine to determine a set-back distance for nesting Black Skimmers (Rynchops niger). Because flight had demonstrated negative effects on reproduction, Burger et al. (2010) chose to use the $95^{\text {th }}$ percentile of distance to first flight $(116 \mathrm{~m})$ as the set-back distance. They discussed that the maximum value for first response was $136 \mathrm{~m}$ and thought there was little difference in these set-backs from an implementation perspective. I decided to use a similar measure to first response distance and called this agitation distance (the distance when a bird first changes its 
behavior) as it is conservative, non-invasive measure of boat-related disturbance to seabirds.

Use of the agitation distance analyzed using a Kaplan Meier survival analysis facilitates a closer examination of the variables of species, boat type, habituation and seasonality and their effect on birds. 


\section{Methods}

\section{Field sampling}

\section{Study areas.}

Six general study areas (Figure 1) off the coast of Vancouver Island, British Columbia were chosen due to the presence of nesting seabird colonies and concurrent presence of recreational or fishing boats:

- Victoria (including Chain Islets, Race Rocks, Arbutus Island and Mandarte Island);

- Southern Gulf Islands (including Galiano Bluffs, Rose and Canoe Islets up to Crofton);

- Nanaimo (including Snake Island, Gabriola cliffs and Five Fingers Island);

- Pacific Rim Park (including Starlight Reef and Barkley Sound);

- Clayoquot Sound (including Cleland Island, Wilf Rock, Monk Rock ),

- Mitlenatch Island off Campbell River 


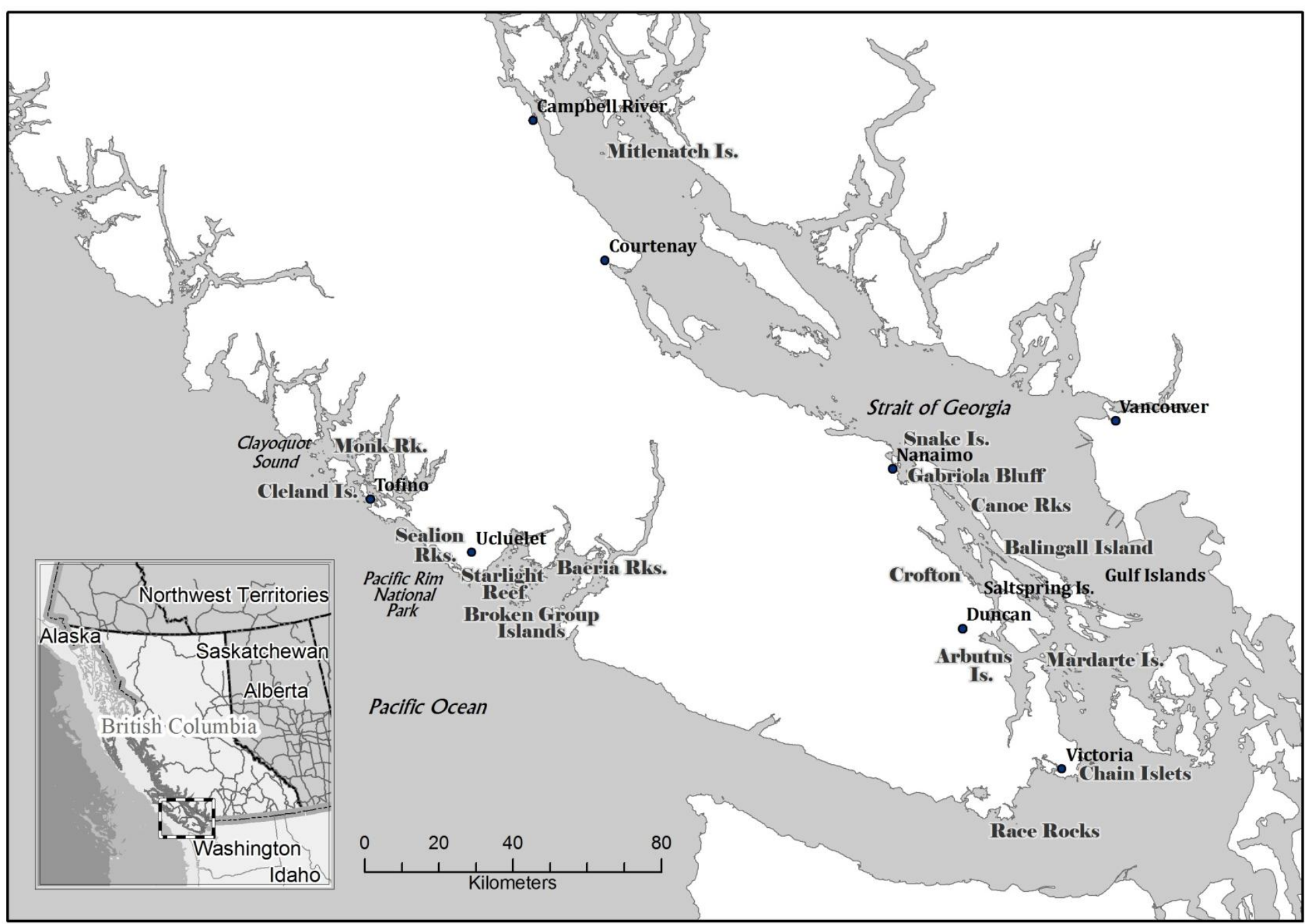

Figure 1 Study areas on Vancouver Island showing major seabird nest and roost sites (Fetherston, 2010). 
As a measure of habituation, each roost or nest location was categorized as to the degree of boat traffic during summer. Based on personal experience before and during the study and consultation with local experts, boat traffic was rated as High (at least 6 boats pass in the vicinity each day), Medium ( 1 or 2 boats per day) or Low (less than 1 boat per day). In total there were 15 nest sites with various nesting combinations of Pelagic Cormorants, Double-crested Cormorants, Brandt's Cormorants, Pigeon Guillemots (Cepphus columba), Glaucous-winged Gulls (Larus glaucescens), and Black Oystercatchers (Haematopus bachmani) sampled. There were approximately 50 different roost sites with the above-mentioned birds, plus Harlequin Ducks (Histrionicus histrionicus), and shorebirds.

Within each study area a motorboat was used to drive through the study area locating birds at roost or nest sites. In the Victoria and Southern Gulf Islands a $6 \mathrm{~m}$ long aluminum boat operated by BC Conservation Officers was used. In the Nanaimo area a volunteer fisherman used a $5 \mathrm{~m}$ fiberglass boat. In the Barkley Sound and Pacific Rim Park area, Parks Canada wardens operated a $4 \mathrm{~m}$ inflatable boat and in Clayoquot Sound and Mitlenatch Island, BC Parks rangers operated an $8 \mathrm{~m}$ aluminum boat. The motorboats approached the test location similarly. When a roost or nest site with seabirds was observed from a distance of approximately $200 \mathrm{~m}$, the boat slowed to about $3 \mathrm{knots}(5.6 \mathrm{~km} / \mathrm{hr})$ in order to begin the tests. A single kayak was carried on each motorboat and this was launched in order to conduct the tests.

An attempt was made to sample each study area three times during the breeding season to determine if time of year had an effect on disturbance distances. Although it appeared that there was variation in nesting stage among the cormorants colonies sampled and between species and sites, the date of survey was assigned 'Early' from 15 May to 15 June, 'Mid-season' from 16 
June to 15 July and 'Late season' from 16 July to 10 August. The majority of tests were conducted in 2006 with additional tests done in 2009.

The field test involved driving the motorboat slowly (ca. 4-6 km/hr) or paddling the kayak directly towards the islet with the roost and/or nest site. Species and numbers of birds were recorded and distances were measured with a Bushnell Yardage-Pro Rangefinder. The distance from the colony or roost at which the test started and the distance that the birds showed a visible agitation reaction to the approach were recorded. Agitation was characterized by activities such as alertness, neck raising, looking back and forth, or standing up more erect. At any one of these visible signs of agitation, this agitation distance was recorded and the boat backed away. The intention was not to make birds fly, but if they did, the number of birds taking off and the distance between vessel and birds was recorded (Appendix 1 Data collection form).

The rangefinder used in 2006 was only able to record distances above $15 \mathrm{~m}$. Distances less than this were estimated or recorded as "not disturbed". Groupings of birds (separated from other groups far enough to not be affected by agitation or flights made by birds in adjacent tests) constituted one test and each species encounter was recorded as one test. In rough sea conditions it was not possible to closely approach certain sites. In this case, the last distance with no disturbance was recorded. The kayak tests were conducted if sea conditions permitted and birds were not reacting to external stimuli such as an over flight by a Bald Eagle (Haliaeetus leucocephalus). The kayaker had a marine radio to communicate the distances, species and bird numbers to a recorder aboard the motorboat. The order of testing with the motor boat and kayak was randomized to reduce the chance of acclimatization. In cases where flight had occurred, we left that particular site but returned after more than $30 \mathrm{~min}$ to repeat the test. The data sheet includes fields for date, locality, motorboat or kayak, boat traffic, bird species, roost or nest, 
number in group, distance test started, distance to agitation (from boat to bird), distance to flight and comments.

\section{Data analysis}

Data were analyzed using the ' $R$ ' statistical software program ( $R$ Development Core Team, 2008). The distance to agitation was the focus of the analysis as there was not enough flight data to analyze and the former was considered to be a more conservative estimate of disturbance. Various authors (Blumstein et al., 2003; Carney \& Sydeman, 1999; Erwin, 1989) indicated that the distance at which birds might be disturbed is dependent on species sensitivity, timing of disturbance (seasonal and time of day), approach type and habituation or previous exposure to human activity. Using agitation distance as the response variable, I first analyzed the species sensitivity, then examined whether nesting made a difference to agitation distance. As kayakers were able to paddle very close to seabird roosts and nest sites and because a kayaker could make a quiet and sudden approach to birds, it was important to experimentally test if kayaks or motorboats had the same response distances. Boat traffic (as a categorical variable of habituation) and survey period were compared to determine if they affected the agitation distance. Data on sea conditions were not analyzed as most tests occurred in weather when boats could go out (swell height less than a meter and wind less than $15 \mathrm{~km}$ ).

Boxplots for species were constructed to illustrate the median and range of agitation distance for tests where there was disturbance. Brandt's Cormorant, Pelagic Cormorant, Doublecrested Cormorant, Black Oystercatcher, Glaucous-winged Gull, Harlequin Duck and Pigeon Guillemot had sample sizes large enough to be included in this preliminary analysis to examine species sensitivity. 
Survival analysis involves the modeling of time or distance to a discrete event (Lawless, 2002). In our analyses, I took the agitation of a focal bird or group of birds as the discrete event of interest, and modeled the survival function $S(d)$ as a function of the distance from the bird. The Kaplan Meier survival method is one way to estimate this survival function, and is particularly appropriate for our data as it makes no parametric assumptions about the form of the survival function being estimated (Lawless, 2002; Sharma, 2005). In the context of this disturbance study, I turned the usual framework of a survival analysis around so that our survival function was fit as the distance to agitation from an origin where no birds were disturbed (200 $\mathrm{m})$. The inference is the complement of this, and instead is the distance from the nest or roost when agitation was recorded.

During data collection, there were times when the boat couldn't get close enough to elicit a behavioral response from the birds due to waves or rocks, thus these data are "censored" at the last approach distance. A major advantage of using survival analysis is that censored data contribute to the estimate of the survival curve rather than being omitted as missing data.

The survival analysis formula is as follows: Let $\mathrm{D}$ represent the random variable for agitation distance from a $200 \mathrm{~m}$ starting point, where the distribution of $\mathrm{D}$ can be characterized by the survival function. The survival function is defined as the cumulative probability of a bird having an agitation distance (D) exceeding a distance $d$, or $S(\mathrm{D}>d)$. For a sample of $N$ disturbance trials for a single species, the ordered agitation distances can be denoted as: $d_{1} \leq d_{2} \leq$ $d_{3} \leq \ldots \leq d_{\mathrm{N}}$. Corresponding to each agitation distance $\left(d_{i}\right)$, is the number of birds $n_{i}$ "at risk" just prior to distance $d_{i}$, and the number of agitated birds $y_{i}$, at distance $d_{i}\left(y_{i}=1\right.$ or 0 for each trial, 
unless the distance agitated was identical between trials). The intervals between each distance typically will not be uniform.

For example, from my data set of 21 disturbance trials for Harlequin Ducks, the first three ordered agitation distances were at 30, $20 \mathrm{~m}$, and, a time when the boat couldn't get close enough for agitation (a censored case), $25 \mathrm{~m}$ from the roost site. Then we have $\left(d_{1}=200-30=\right.$ $170 \mathrm{~m}, d_{2}=200-25=175 \mathrm{~m}($ censored $\left.), d_{3}=200-20=180 \mathrm{~m}\right),\left(n_{1}=21, n_{2}=20, n_{3}=19\right)$, and $\left(y_{1}=1, y_{2}=0, y_{3}=1\right)$.

$$
\hat{S}(D>d)=\prod_{d_{i}<d} \frac{n_{i}-y_{i}}{n_{i}} \text { for } \mathrm{i}=1, \ldots, 21 . \mathrm{g}
$$

In this example, the survival function at $20 \mathrm{~m}\left(\hat{S}\left(D>d_{3}\right)=200-20=180 \mathrm{~m}\right)$ would be solved by the following: $\hat{S}(\mathrm{D}>180 \mathrm{~m})=\left(\frac{21-1}{21} * \frac{20-0}{20} * \frac{19-1}{19}\right)=0.902$. This shows a $90.2 \%$ probability that a boat can get within $20 \mathrm{~m}$ without causing agitation and was interpreted as $10 \%$ probability of agitation (rounded to the nearest percent).

Survival-type curves for distance to agitation were plotted by species for roosting and nesting birds. Species were pooled for statistical testing of boat type, boat traffic and seasonal timing. The logrank test (Harrington, 2005) was used to compare the survival distributions between motor boat and kayak and among boat traffic categories and the three seasonal periods. 


\section{Results}

\section{Agitation response distance}

Data were analyzed for 517 tests on the roost and nest sites. Pelagic Cormorants, Glaucous-winged Gulls, Double-crested Cormorants, Pigeon Guillemots, Black Oystercatchers, Brandt's Cormorants and Harlequin Ducks had enough samples to analyze agitation distances by species with other interaction factors. Other species, including shorebirds, Bald Eagles,

Heermann's Gulls (Larus heermanni), California Gulls (Larus californicus) and Common Murres, were not encountered frequently on the nest and roosting islets and were only included in analyses that were not species specific, such as boat vs. kayak, and the boat traffic analysis.

\section{Agitation distances for seabirds by species}

Boxplots including roosting and nesting birds and pooled data from motor boats and kayaks where there was agitation show that Brandt's Cormorant and Harlequin Ducks were the most sensitive species with a median agitation distance of $70 \mathrm{~m}$ and $51 \mathrm{~m}$, respectively. Doublecrested Cormorant, Pelagic Cormorant, Glaucous-winged Gull, Pigeon Guillemot and Black Oystercatcher had lower median agitation distances ranging between 23 and $30 \mathrm{~m}$ (Figure 2). 


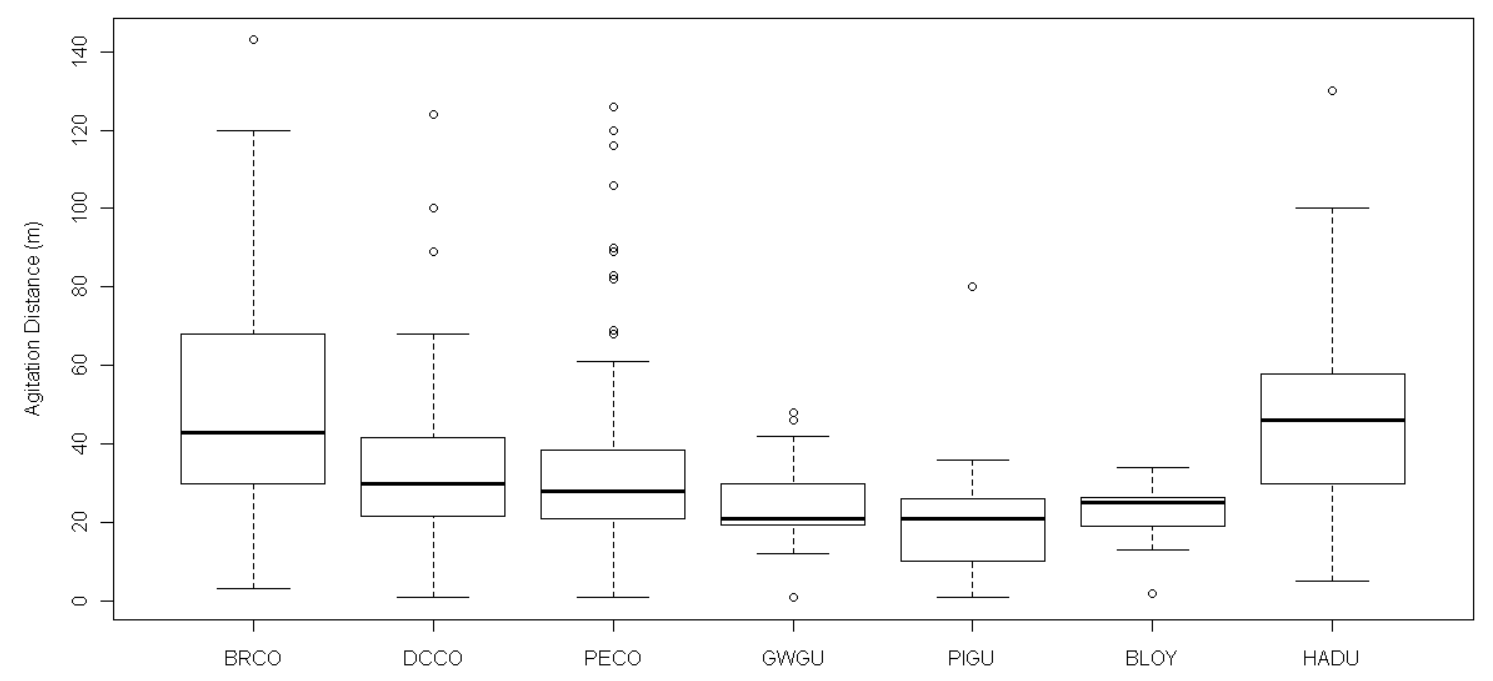

Figure 2 Agitation distances by species.

Boxplots showing agitation distances by species combining data for both roosting and nesting seabirds. The data shown are medians (thick horizontal line), 50\% observations (boxes), range (whiskers) and outliers (open circles). BRCO = Brandt's Cormorant (34 tests), DCCO = Doublecrested Cormorant (71 tests), PECO = Pelagic Cormorant (193 tests), GWGU = Glaucouswinged Gull (86 tests), PIGU = Pigeon Guillemot (43 tests), BLOY = Black Oystercatcher (42 tests), HADU = Harlequin Duck (27 tests).

\section{Agitation distances for nesting seabirds}

Using data (199 tests) where agitation occurred for nesting Double-crested Cormorant, Pelagic Cormorant, Glaucous-winged Gull, Pigeon Guillemot and Black Oystercatcher the median agitation distance ranged between $22 \mathrm{~m}$ for Pigeon Guillemots and $30 \mathrm{~m}$ for Doublecrested Cormorants (Figure 3). The single nesting record for Brandt's Cormorant is not shown. 
Nesting Data Only: Agitation Distance

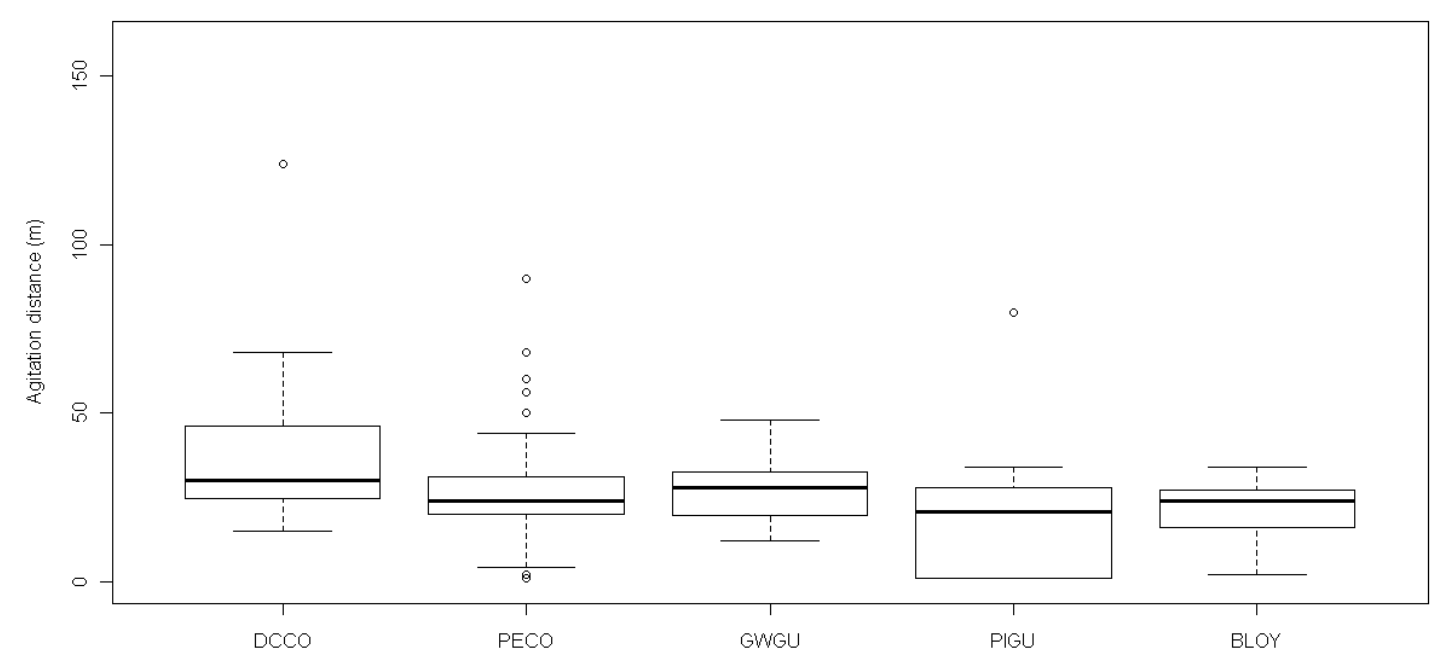

Figure 3. Boxplots for agitation of nesting seabirds

Boxplots showing median (solid horizontal lines), 50\% samples (boxes), range (whiskers) and outliers (open circles) for agitation distance for nesting seabirds. $\mathrm{DCCO}=$ Double-crested Cormorant (28 tests), PECO = Pelagic Cormorant ( 93 tests), GWGU = Glaucous-winged Gull (41 tests), PIGU = Pigeon Guillemot (19 tests), BLOY = Black Oystercatcher (18 tests).

\section{Agitation distances for roosting seabirds}

Using data for roosting seabirds (372 tests), the median agitation distance (in cases where agitation occurred) for Brandt's Cormorants was $68 \mathrm{~m}$, Harlequin Ducks was $55 \mathrm{~m}$ and the other species ranged from $35 \mathrm{~m}$ for Pelagic Cormorants to $21 \mathrm{~m}$ for Glaucous-winged Gull (Figure 4). 


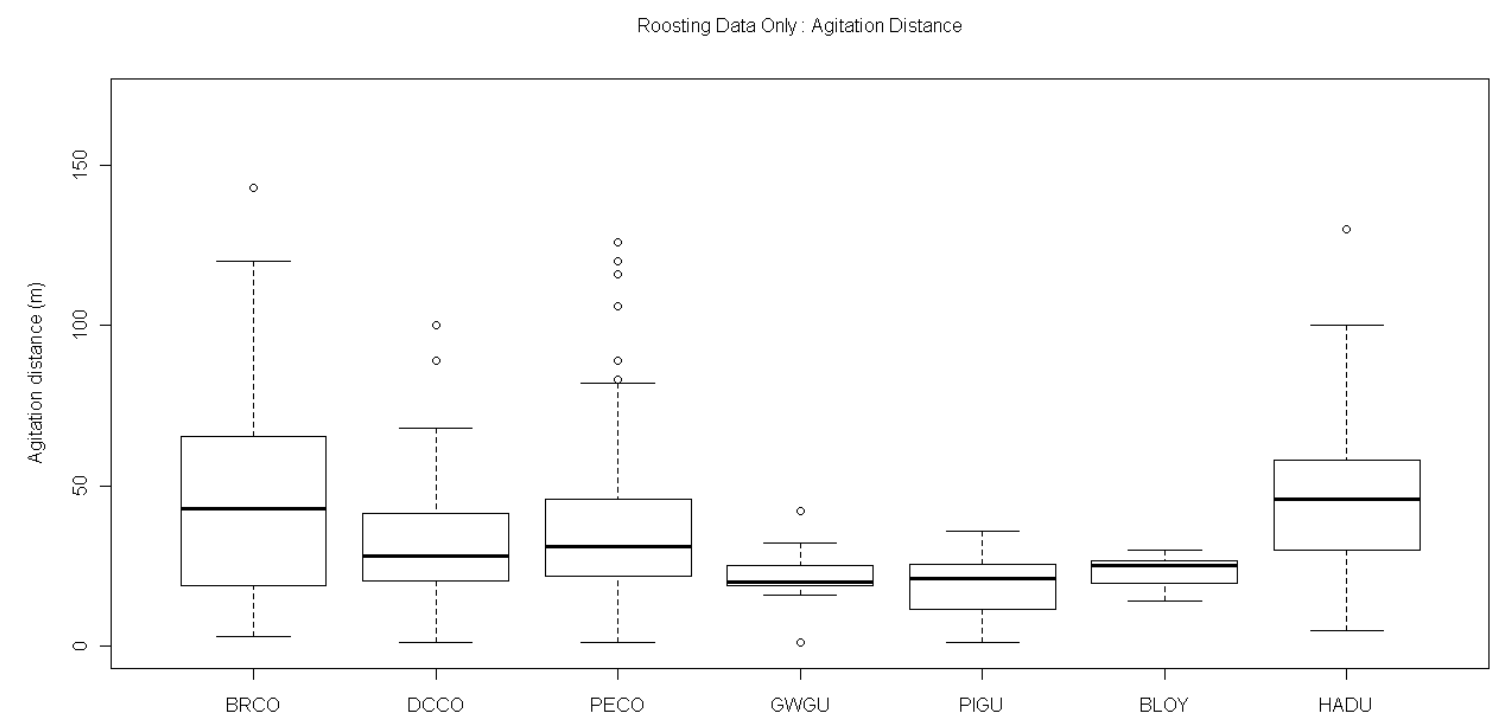

Figure 4 Boxplots of agitation distance for roosting seabirds.

Boxplots showing median (solid horizontal lines), 50\% samples (boxes), range (whiskers) and outliers (open circles) for agitation distance for roosting seabirds. BRCO $=$ Brandt's Cormorant (32 tests), $\mathrm{DCCO}=$ Double-crested Cormorant (47 tests), $\mathrm{PECO}=$ Pelagic Cormorant (116 tests), GWGU = Glaucous-winged Gull (62 tests), PIGU = Pigeon Guillemot (31 tests), $\mathrm{BLOY}=$ Black Oystercatcher (36 tests), HADU = Harlequin Duck (27 tests).

\section{Agitation distances tested with survival analysis}

Of the 513 disturbance tests for the seven species of seabird, pooling motor boat and kayak tests, there were 122 tests where there was no agitation or where the boat could not approach closer to the islets due to rocks or ocean swell. These data were included in plotted distribution curves showing the proportions of agitated birds compared to distance. The logrank test showed that there was a significant difference between the agitation distance distributions for roosting and nesting seabirds $\left(X^{2}=8.1, \mathrm{df}=1, p=0.005\right)$. Therefore nesting and roosting birds were analyzed and plotted separately by species (Figures 5 and 6 , and Table 1). At distances less 
than $40 \mathrm{~m}$ the proportions of nesting birds agitated were similar among Black Oystercatchers (8\%), Pigeon Guillemots (6\%), Glaucous-winged Gulls (3\%), Double-crested Cormorants (5\%), and Pelagic Cormorants (3\%). At $50 \mathrm{~m}$, the chance of agitation decreased to $0 \%$ for the nesting species, except for Pelagic Cormorants with a $2 \%$ chance of .agitation.

Overall roosting seabirds were more sensitive than nesting birds to boat disturbance (Figure 6, Table 1). Harlequin Ducks were the most sensitive species at roosts with $25 \%$ agitated at less than $50 \mathrm{~m}$ and $44 \%$ were agitated at distances less than $40 \mathrm{~m}$. Brandt's Cormorants were sensitive with 16-20\% agitated at less than $50 \mathrm{~m}$ and $45 \%$ agitated at distances less than $40 \mathrm{~m}$. Roosting Pelagic Cormorants were somewhat sensitive with $17 \%$ agitated at distances less than 50 m. Roosting Glaucous-winged Gulls, Black Oystercatchers and Pigeon Guillemots were not sensitive and had less than $10 \%$ agitated at distances less than $30 \mathrm{~m}$. At a distance of $70 \mathrm{~m}$ the more sensitive Harlequin Duck and Brandt's Cormorant and had about 10\% chance of agitation. 
NESTING BIRD DATA

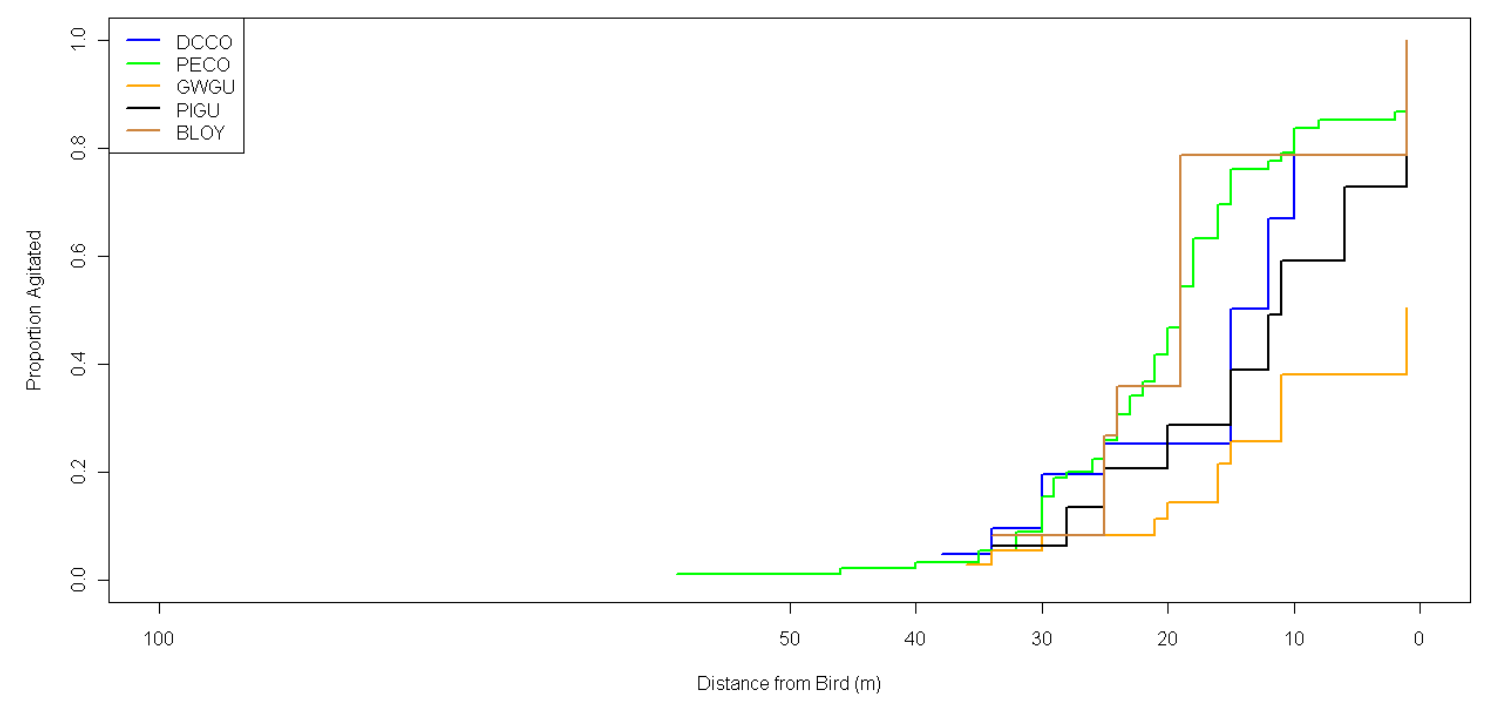

Figure 5. Plot of the proportions of nesting seabirds agitated at varying distances.

Plot of the proportions of nesting seabirds agitated at varying distances as predicted by KaplanMeier survival analysis. Truncations (where no line exists) in the lines as they approach $100 \mathrm{~m}$ means there were no agitation after that particular distance. $\mathrm{DCCO}=$ Double-crested Cormorant (28 tests), PECO = Pelagic Cormorant (93 tests), GWGU = Glaucous-winged Gull (41 tests), PIGU = Pigeon Guillemot (18 tests), BLOY = Black Oystercatcher (18 tests). 
ROOSTING BIRD DATA

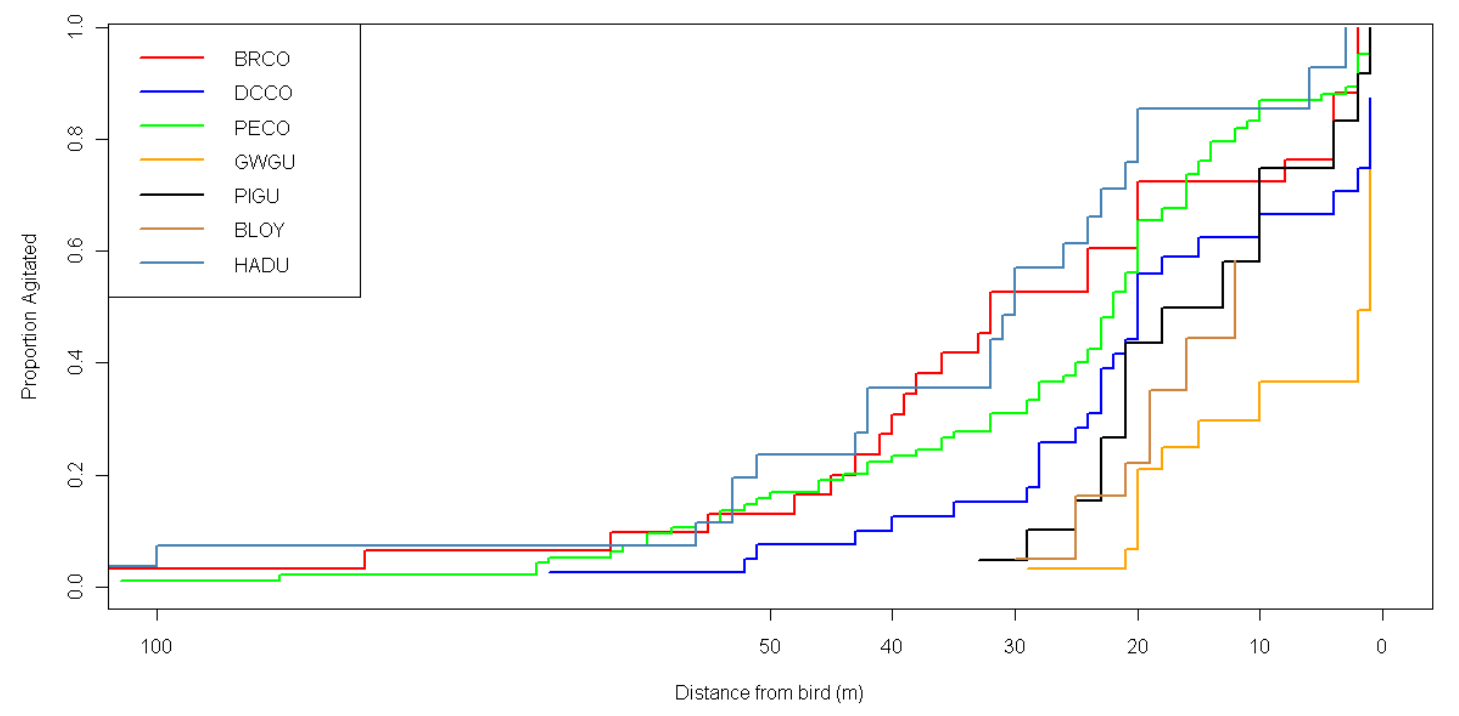

Figure 6 Plot of the proportions of roosting seabirds agitated at varying distances.

Plot of the proportions of roosting seabirds agitated at varying distances as predicted by KaplanMeier survival analysis. Truncations (where no line exists) in the lines as they approach $100 \mathrm{~m}$ means there were no agitation after that particular distance. $\mathrm{BRCO}=$ Brandt's Cormorant (33 tests) $\mathrm{DCCO}=$ Double-crested Cormorant (43 tests), PECO = Pelagic Cormorant (100 tests), GWGU = Glaucous-winged Gull (45 tests), PIGU = Pigeon Guillemot (24 tests), BLOY = Black Oystercatcher (24 tests), HADU = Harlequin Duck (27 tests). 
Table 1. Probability of agitation for nesting and roosting seabirds

Kaplan Meier estimate of probability (number rounded to nearest percent) of nesting and roosting birds being agitated at 70, 50, 40 and $30 \mathrm{~m}$ approach distances. Standard error (SE) is on estimate of probability agitated. If no SE is shown, there were no tests with agitation at that distance. Brandt's Cormorants and Harlequin Ducks did not nest in the study area.

\begin{tabular}{|l|c|c|c|c|c|c|c|c|c|}
\hline \multirow{2}{*}{} & \multicolumn{2}{|l|}{ Probability (\%; SE in parentheses) of agitation at these approach } \\
distances
\end{tabular}




\section{Motorboat vs. kayak agitation distances}

Using pooled data for all species with the motorboat (327 tests) $3 \%, 9 \%, 26 \%$ and $31 \%$ of seabirds were agitated at 70, 50, 40 and 30 m respectively. With 186 tests with the kayak 2\%, $4 \%, 7 \%$ and $14 \%$ of seabirds were agitated at $70,50,40$, and $30 \mathrm{~m}$ respectively (Table 2 ). The motorboat and kayak distributions have a similar shape and confidence intervals overlap in a few instances (Figure 7). However, the logrank test comparing agitation distributions showed that the kayak could approach significantly closer to the birds without agitation than the motor boat $\left(X^{2}=19.7, \mathrm{df}=1, p<0.0001\right)$.

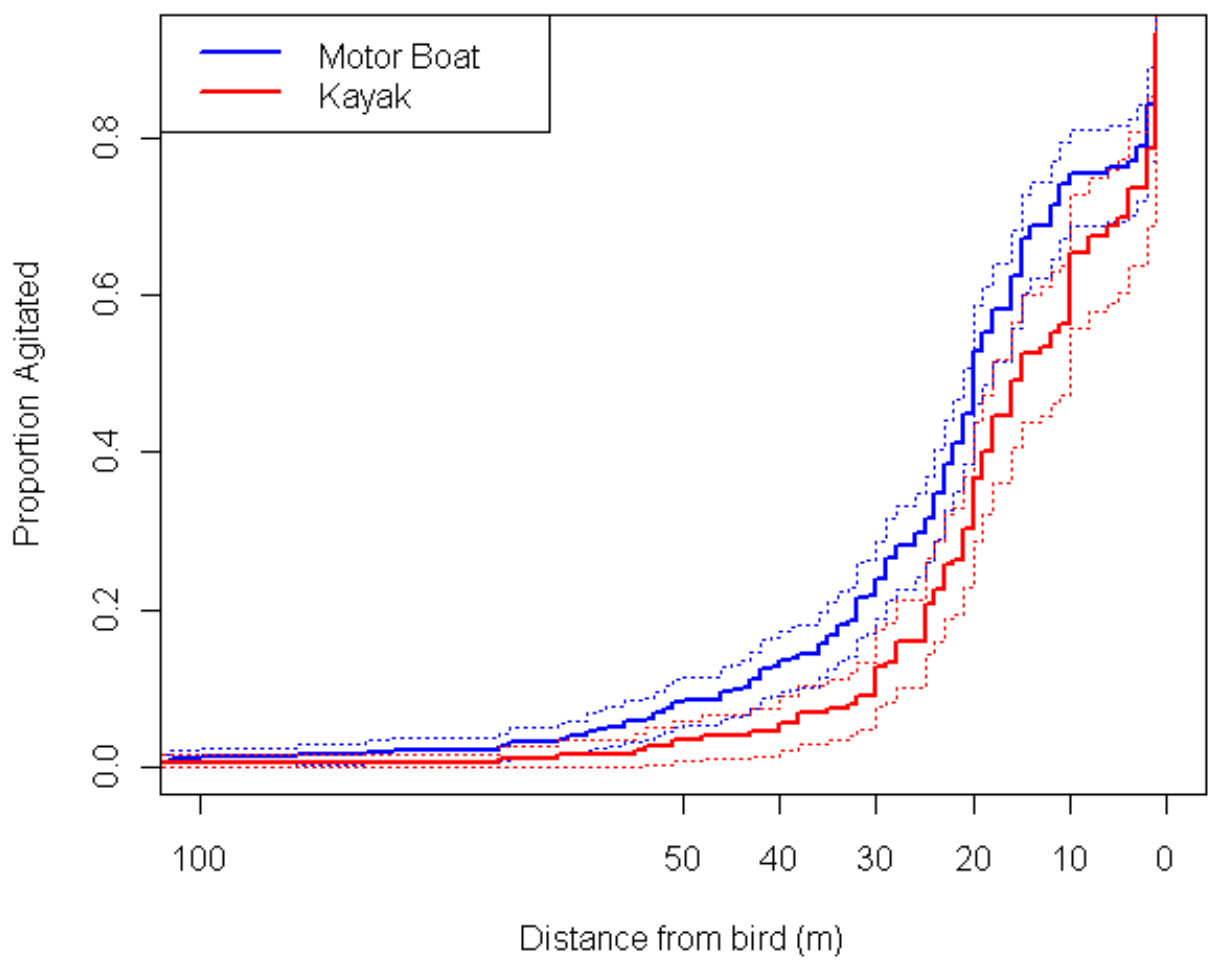

Figure 7. Plot of birds agitated by motorboat and kayaks.

Kaplan Meier estimate of proportions of birds agitated when approached by a motorboat and a kayak, using pooled data from all bird species. Dotted lines show $95 \%$ confidence intervals 
Table 2 Probability of agitation for kayaks and motorboats.

Kaplan Meier estimate of percentage or proportion (number rounded to nearest percent) of seabirds agitated at $70,50,40$ and $30 \mathrm{~m}$ in kayak $(\mathrm{n}=186)$ or motorboat $(\mathrm{n}=327)$ tests. Standard error is on estimate of percentage agitated.

\begin{tabular}{|l|c|c|c|c|}
\hline \multirow{2}{*}{} & \multicolumn{4}{|c|}{$\begin{array}{l}\text { Probability (\%; SE in parentheses) of agitation at these approach } \\
\text { distances }\end{array}$} \\
\cline { 2 - 5 } & $70 \mathrm{~m}$ & $50 \mathrm{~m}$ & $40 \mathrm{~m}$ & $30 \mathrm{~m}$ \\
\hline Kayak & 2 & 4 & 7 & 14 \\
& $(<1)$ & $(2)$ & $(2)$ & $(3)$ \\
\hline Motorboat & 3 & 9 & 15 & 26 \\
& $(<1)$ & $(2)$ & $(2)$ & $(3)$ \\
\hline
\end{tabular}

\section{Effects of boat traffic on agitation distance}

There were 133 tests at sites classified as High boat traffic which included Great Chain Island, Cleland Island, Race Rocks Ecological Reserves and Mandarte Island where tour and recreational fishing boats pass regularly. There were 95 tests at the Low boat traffic sites including Starlight Reef, Great Bear Reef, Sea-lion Rocks and Faber Islet in Pacific Rim National Park and Baeria Rocks Ecological Reserve (all on the west coast of Vancouver Island). The remainder of sites (269 tests) including Galiano Bluffs, Snake Island, Gabriola Bluffs, Arbutus Island and Crofton were classified as Medium boat traffic. The data were analyzed based on 8 species of seabird pooling motorboat, kayak, nesting and roosting (Table 3). At all the approach distances summarized $(70,50,40$ and $30 \mathrm{~m})$ the proportion of birds agitated was always highest with Low boat traffic, intermediate at Moderate, and lowest at High traffic sites (Table 4). 
Table 3. Number of tests of various seabird species at High, Medium and Low boat traffic sites.

\begin{tabular}{|c|c|c|c|c|c|c|c|c|c|}
\hline $\begin{array}{l}\text { Boat } \\
\text { traffic }\end{array}$ & 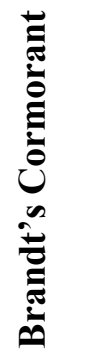 & 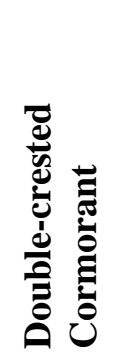 & 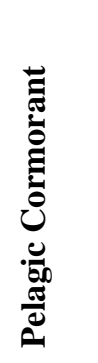 & 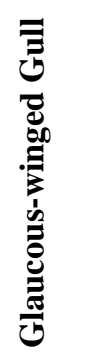 & 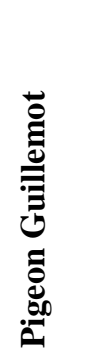 & 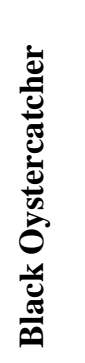 & 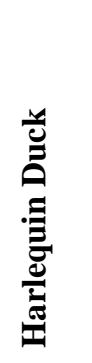 & 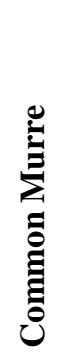 & 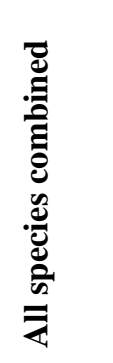 \\
\hline High & 5 & 19 & 52 & 24 & 24 & 7 & 1 & 1 & 133 \\
\hline Medium & 8 & 52 & 120 & 41 & 17 & 19 & 12 & 0 & 269 \\
\hline Low & 21 & 0 & 21 & 21 & 2 & 16 & 14 & 0 & 95 \\
\hline
\end{tabular}

Table 4. Probability of seabirds agitated at various distances at High, Medium and Low Boat traffic sites.

\begin{tabular}{|c|c|c|c|c|}
\hline & \multicolumn{4}{|c|}{ Percent probability agitated (Standard error in brackets) } \\
\cline { 2 - 5 } & $\mathbf{7 0 ~} \mathbf{~ m 0 ~ m ~}$ & $\mathbf{4 0 ~} \mathbf{~}$ & $\mathbf{3 0} \mathbf{~ m}$ \\
\hline $\begin{array}{c}\text { High boat } \\
\text { traffic }\end{array}$ & 0 & 1 & 2 & 8 \\
\hline $\begin{array}{c}\text { Medium } \\
\text { boat traffic }\end{array}$ & 1 & $(1)$ & $(1)$ & $(2)$ \\
\hline $\begin{array}{c}\text { Low boat } \\
\text { traffic }\end{array}$ & $(<1)$ & $(1)$ & 9 & 20 \\
\hline
\end{tabular}

There was significant difference $\left(\mathrm{X}^{2}=50.7, \mathrm{df}=1, p<0.001\right)$ between the agitation distributions at the three boat traffic levels (Figure 8). Clearly, seabirds were seldom agitated beyond $70 \mathrm{~m}$ at any boat traffic category, while at distances less than $30 \mathrm{~m}$, higher percentages of seabirds were agitated. There was no agitation for High boat traffic sites beyond $50 \mathrm{~m}$. High and Medium boat traffic sites were approached significantly closer without agitation than Low boat traffic sites. There is some overlap of confidence intervals (dotted lines) between High and 
Medium boat traffic tests showing less difference in agitation distance between these sites. Habituation to boat traffic therefore reduced the probability of disturbance from approaching boats.

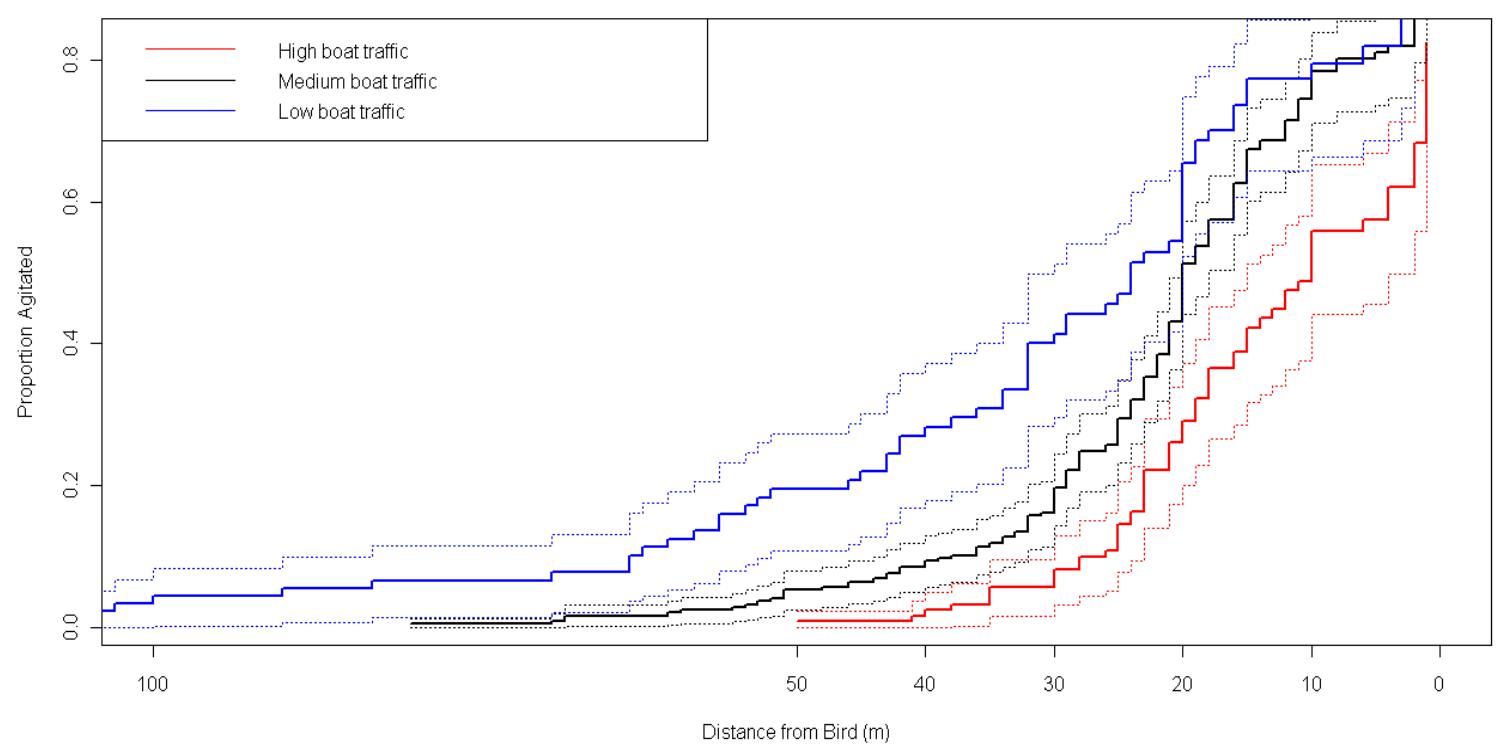

Figure 8. Seabird agitation at High, Low and Medium boat traffic

Kaplan- Meier estimate of the proportion of roosting and nesting seabirds agitated at High, Low and Medium boat traffic sites plotted against distance of boat or kayak from bird. The dotted lines are the $95 \%$ confidence intervals.

As Brandt's Cormorants were agitated at greater distances than other seabirds and only occurred on the west coast of Vancouver Island where all the Low boat traffic sites were located, a separate analysis was conducted to determine if boat traffic effects were related to the distribution of this particular species. The probability of agitating Brandt's Cormorants at $40 \mathrm{~m}$ distance at High, Medium and Low boat traffic sites was 20\%, 50\% and 37\%, respectively, and 
there was no significant difference in the proportions agitated (Logrank test; $X^{2}=2.1, \mathrm{df}=2, p=$ 0.356). Boat traffic as a measure of habituation does not account fully for the longer response distance thresholds for Brandt's Cormorant.

\section{Seasonal timing of disturbance and agitation distance for nesting birds}

Nesting Double-crested Cormorants, Pelagic Cormorants, Glaucous-winged Gull, Pigeon Guillemot, and Black Oystercatcher were included in the early, mid and late breeding season analysis (Table 5). There was no significant difference (logrank test; $X^{2}=3.5, \mathrm{df}=1, p=0.175$ ) in proportions agitated between the three breeding periods.

Table 5 Probability of nesting seabirds being agitated at 50, 40 and $30 \mathrm{~m}$ approach distances during early, mid and late breeding season.

\begin{tabular}{|l|c|c|c|}
\hline \multirow{2}{*}{ Season } & \multicolumn{3}{|c|}{ Percent probability agitated (Standard error) } \\
\cline { 2 - 4 } & $\mathbf{5 0} \mathbf{~ m}$ & $\mathbf{4 0} \mathbf{~ m}$ & $\mathbf{3 0 ~} \mathbf{~}$ \\
\hline $\begin{array}{l}\text { Early } \\
\text { 15 May - } \\
\text { 15 June } \\
\mathrm{n}=94\end{array}$ & 1 & 2 & 17 \\
\hline $\begin{array}{l}\text { Mid } \\
\text { 16 June - 15 }\end{array}$ & $(1)$ & $(2)$ & $(4)$ \\
$\begin{array}{l}\text { July } \\
\mathrm{n}=37\end{array}$ & 0 & 0 & 6 \\
\hline $\begin{array}{l}\text { Late } \\
16 \text { July }- \\
10 \text { Aug } \\
\mathrm{n}=65\end{array}$ & 3 & & $(4)$ \\
\hline
\end{tabular}




\section{Discussion}

\section{Factors affecting disturbance response}

\section{Roosting vs. nesting}

The results of this study indicate that roosting and nesting seabirds on Vancouver Island respond differently to boat approach. Nesting birds allowed a closer approach by a boat before showing agitation than did roosting birds. In terms of fitness, a nesting bird must evaluate the cost and benefits of staying on the nest to defend its eggs or young or fleeing to protect itself (Montgomerie \& Weatherhead, 1988). Since seabirds are generally long-lived and have high adult survival, their populations are sensitive to adult mortality (Gaston, 2004). Therefore as a strategy, seabirds, particularly cormorants, will flee when under predation risk as they can re-nest later in the season or in another year (Moul \& Gebauer, 2002). However, nesting seabirds have little to gain by responding to boat approach before it is necessary. Flight could cause exposure of eggs or chicks to predation by Northwestern Crows (Corvus caurinus), Bald Eagles or gulls. Thermal stress (cold or hot) from flushing could also lead to a loss of reproduction for that season and an energetic loss. It follows then, that nesting birds will stay at the nest and not show agitation at closer distances than roosting seabirds. Roosting birds responding to a perceived risk by a boat risk face only an energetic loss or a temporary displacement if the response is unwarranted and would therefore be more inclined to be agitated and flee at farther approach distances.

Despite the trend for less sensitivity of nesting birds, there were a couple of exceptions. Black Oystercatchers had a 27\% chance of being agitated at distances less than $30 \mathrm{~m}$ when nesting, while only a $5 \%$ chance of agitation at this distance when roosting. Black Oystercatchers nest on the surface of a barren rocky islet or beach and crouch low down to avoid 
being noticed. Their nests are very vulnerable to predation if the adult leaves the nest. The low sample size for Black Oystercatchers was due to the fact that nesting birds are particularly difficult to detect from a boat. They are highly distressed by humans landing or walking near their nest and it follows that they are most agitated at close proximity to the nest. Since Black Oystercatchers are a species of high viewing interest, it is important to know that roosting birds can tolerate closer approach, while nest sites require protection especially from landing boats and foot traffic.

Pigeon Guillemots have nests that are hidden in rock crevices. They appeared to be reasonably tolerant of boat approach when roosting but had the highest proportion agitated at distances less than $40 \mathrm{~m}$ when nesting. Nesting Pigeon Guillemots were often observed swimming or holding fish directly off their nest sites. At $50 \mathrm{~m}$ there were few agitated Pigeon Guillemots and with this set-back distance, swimming Pigeon Guillemots would be protected as well.

Nesting sites for seabirds on Vancouver Island are limited by the availability of sites free of ground predators (e.g., mink Mustela vison, raccoon Procyon lotor, dogs, and cats). As well, a heavy-bodied diving bird such as a cormorant requires an elevated perch to take off. Nest sites are on islands, rocky islets and cliff faces. The cormorants observed in this study tended to nest on cliff ledges such as Gabriola or Galiano Bluffs or the highest parts of islands with close marine access (e.g., Mitlenatch Island). Nest sites on Vancouver Island also tend to be important roost sites at all times of year. Since nest sites are crucial to maintaining seabird populations, the set-back distance must ensure that nesting areas for seabirds are protected. A set-back distance of $50 \mathrm{~m}$ would ensure that surface-nesting seabird species were protected. 


\section{Species sensitivity}

In common with other studies (Beale, 2007; Blumstein et al., 2003; Rodgers \&

Schwikert, 2002), differential species sensitivity had a strong effect on the distances that birds on Vancouver Island became agitated. Clearly, roosting Harlequin Ducks, Pelagic Cormorants and Brandt's Cormorants responded to boat traffic at farther distances than did Double-crested Cormorants, Pigeon Guillemots, Glaucous-winged Gulls and Black Oystercatchers. Cormorants seem particularly sensitive, and I found a strong increase in the proportions agitated between 40 $\mathrm{m}$ to $30 \mathrm{~m}$ threshold for all three cormorant species. Other authors report similar sensitivity of Pelagic, Double-crested and Brandt's Cormorants to disturbance especially in the early stages of nesting (Anonymous, 2008; Cairns et al., 1998; Moul \& Gebauer, 2002; Vermeer \& Rankin, 1994).

My data suggest that site-specific set-backs are needed where two highly sensitive species, Harlequin Ducks and Brandt's Cormorants, occur. Although Harlequin Ducks are not atrisk in British Columbia (B.C. Conservation Data Centre, 2010), they are a species that is considered to be sensitive and likely declining (Rodway et al., 2003). Goudie and Ankney (1986) reported that due to their small body size and high winter feeding rates, Harlequin Ducks have little flexibility to accommodate increased stress. During the late spring-early summer time when my study was conducted male Harlequin Ducks congregate in molting aggregations around small islets. As they cannot always fly when they are molting, Harlequin Ducks are sensitive to disturbance at this time. In my southern Vancouver Island study area I noted groups of over 5 Harlequin Ducks on Ballingall Islets off Galiano Island, Baeria Rocks Ecological Reserve and on Faber, Plover and Village Reef in the Broken Group Islands section of Pacific Rim Park. Brandt's Cormorants nested on Starlight Reef in Pacific Rim National Park and roosted in 
aggregations of over 5 birds on Barney Rock, Plover Reef, Wilf Rock, Great Bear Reef, Village Reef, Monk Rock and a rock off Cleland Island Ecological Reserve (all on the Pacific coast). Site-specific set-back buffers of $70 \mathrm{~m}$ on most of the above-mentioned islets (exceptions are Barney Rock in Tofino Harbour and Monk Rock which birds showed habituation) would protect roosting aggregations of Harlequin Ducks and Brandt's Cormorants from disturbance while allowing closer access to other seabird viewing sites.

\section{Breeding Chronology}

There was no significant difference in agitation response between Early (before 15 June), Mid (between 16 June and 15 July) and Late (after 16 July) seasons. Other authors working with Black Skimmers, Common Terns (Sterna hirundo) and Great Blue Herons (Ardea herodius) found that pre-incubation was the most sensitive time for flight (Burger et al., 2010; Erwin, 1989; Vennesland, 2010). In the pre-incubation stage of nesting, birds have the lowest amount of energy invested in reproduction and may make a decision to flee and save themselves for another nesting attempt. In my study the lack of significance could be explained by the variety in the various species' breeding chronology. By 15 June Black Oystercatchers had chicks, some Glaucous-winged Gulls had eggs, while cormorants were in the pre-incubation stage (Campbell et al., 1990). Therefore, it would only be feasible to determine the effect of breeding chronology on disturbance response by increasing the sample for each individual species. Since the effect of seasonality was not great enough to be discerned at the overall level, this factor would be considered secondarily. If however, a manager wanted to determine a particular site's sensitivity to disturbance, I recommend testing agitation distance in the period before 15 June. 


\section{Kayak vs. motorboat responses}

My study demonstrated that a single kayak could approach closer to seabird roost and nest sites without an agitation response than a motor boat could. With the kayak at $40 \mathrm{~m}$ there were only $3-10 \%$ of birds agitated. Seabirds likely perceive a group of kayakers as a larger threat than a single kayak and kayakers generally travel in groups. I therefore expect that groups of kayaks would likely illicit a greater response at farther distances than seen in my data from a single kayak. Amato (1995) stressed that kayakers in California and the San Juan islands were very disturbing to seabirds as they were able to approach and land on islands that motorboats could not access. Burger et al. (2010) discuss the value of setting a single set-back distance that is easier to understand, remember and enforce. Therefore, although a single kayak could approach birds at closer range, I recommend a general single set-back distance based upon the motorboat agitation response threshold of $50 \mathrm{~m}$. Kayakers should also be aware of approaching seabird roost and nest sites in a tangential manner, and then going along parallel to shore at the prescribed distance. The tangential approach is less threatening to birds than either a direct approach (Burger \& Gochfeld, 1981) or a stealthy approach from behind rocks. If the Harlequin Duck and Brandt's Cormorant roost aggregate sites are provided the extra $20 \mathrm{~m}$ buffer and a strict no-landing policy is maintained then disturbance to seabirds from kayaks could virtually be eliminated.

\section{Habituation to boat traffic}

Surface-nesting and roosting seabirds on Vancouver Island appeared to habituate to moderate and high levels of boat traffic, which corroborates other researchers' findings. Fowler (1999) demonstrated that Magellanic Penguins (Spheniscus magellanicus) can habituate over 
time to tourist exposure and Burger (1981) showed that gulls were able to habituate to a general stimulus while assessing the threat in particular situations. Nisbet (2000) recommends promotion of habituation in waterbird colonies as it can be beneficial to conservation and will permit and promote beneficial educational and recreational uses.

Although seabirds seem to respond to approaching boats as a predation threat, seabirds at the High and Medium boat traffic sites appear to recognize a true predation threat and seem to have habituated to boat traffic. By comparison, on six occasions during the study at Mandarte Island, Mitlenatch Island, Great Chain Islet and Cleland Island Ecological Reserves, a Bald Eagle flew over the nesting area and caused mass flight and loud alarm calling by gulls, cormorants, oystercatchers and Pigeon Guillemots from an approximate starting distance of about $40 \mathrm{~m}$. These same birds had only shown an agitated response at less than $20 \mathrm{~m}$ with the previous motorboat or kayak tests. Giesbrecht (2001) observed Double-crested Cormorants at Chain, Mandarte and Crofton for 21 days and did not observe a single flushing response to boat traffic but observed flushing from Bald Eagles and eagles eating cormorants on 7 occasions. Cleland Island, Great Chain Islet Ecological Reserves, Mitlenatch Island and Mandarte Island could be approached by boats up to $50 \mathrm{~m}$ which would allow tourists to have satisfactory views of seabirds without disturbance.

\section{Species effects and boat traffic analysis}

While the boat traffic analysis showed that there were effects of habituation, clearly there were also differential species effects. Low sample size for the sensitive individual species at the different boat traffic sites (see Table 3) precluded exact determination of which effect was 
stronger. There was only one High boat traffic site for Harlequin Ducks and there were 21 Low boat traffic sites to 5 High boat traffic sites for Brandt's Cormorants. Although there was no statistically significant difference shown for Brandt's Cormorants at the different sites, I suspect that Brandt's Cormorants also habituate to boat traffic because at Barney Rock in Tofino Harbour where dozens of boats pass daily, there was no response in the test conducted. However, the skewed distribution of Harlequin Ducks to the remoter islets indicates their overall sensitivity. 


\section{Management recommendations for set-backs for seabird nest and roost sites Establishing set-back distances}

Burger et al. (2010) suggested a series of steps to determine appropriate set-back distances which included selecting the behavioral measure of most concern, the most sensitive reproductive stage, the level of response (mean, maximum or in-between) and then deciding whether to establish an additional buffer to reduce risk. Since my study involved multiple species which often co-occur, selecting a suitable buffer for Vancouver Island seabirds should also involve selecting whether to set the distance based on roosting or nesting, which species is the most sensitive to disturbance and whether that species is of management concern.

On Vancouver Island, most major seabird nesting colonies are protected by National or Provincial Parks, Ecological Reserves or (at Galiano Bluffs) Land Conservancy ownership. Notable exceptions are Mandarte Island Indian Reserve, Gabriola Cliffs and Crofton which are unprotected. Managers of protected areas with seabird colonies and roost sites can use zoning of particularly sensitive sites in combination with set-back distance buffers to minimize seabird disturbance while allowing boaters to experience and appreciate the wonder and beauty of a seabird colony. On Vancouver Island, a set-back distance of $50 \mathrm{~m}$ from most seabird nest sites should protect Double-crested Cormorants, Pelagic Cormorants, Pigeon Guillemots, Black Oystercatchers and Glaucous-winged Gulls from boating disturbance. The $50 \mathrm{~m}$ set-back distance will work for all sites in the Salish Sea (Strait of Georgia) with the exception of Harlequin Duck roost sites such as Ballingall Islet. To protect significant roost sites of Harlequin Ducks at Ballingall Islets, Baeria Rocks, Faber Islet, Plover Reef and Village Reef a set-back of $70 \mathrm{~m}$ offshore could be marked. In addition to the above-mentioned sites, sensitive Brandt's 
Cormorant roost sites could be buffered by a 70 m setback at Starlight Reef, Great Bear Reef, and Cormorant Rocks near Cleland Island. As seabird roost sites are not always predictable due to differing prey and environmental conditions, general approach guidelines for all aggregations of seabirds will help boaters remember and be compliant to the recommended setback distance. As most west coast Vancouver Island sites outside the study area are not visited regularly and could be classified as Low boat traffic (eg. Checleset Bay, Scott Islands, Seabird Rocks, Solander Island) a precautionary set-back distance of $70 \mathrm{~m}$ would be in order. 
Table 6. Boating guidelines for viewing roosting and nesting seabirds

\begin{tabular}{|c|c|}
\hline Category & Recommendations \\
\hline Landing & $\begin{array}{l}\text { Do not land on seabird nest or roost sites. Surface-nesting seabirds } \\
\text { are particularly vulnerable to land-based disturbance: }\end{array}$ \\
\hline $\begin{array}{l}\text { Set-back distance } \\
\text { (most areas) }\end{array}$ & Stay $50 \mathrm{~m}$ away from all roost and nesting sites \\
\hline $\begin{array}{l}\text { Set-back distance } \\
\text { (site specific) }\end{array}$ & $\begin{array}{l}\text { Stay } 70 \mathrm{~m} \text { away from these sites: } \\
\text { a) Balingall Islets, Baeria Rocks, Faber Islet, Plover Reef, } \\
\text { Village Reef and other important Harlequin Duck roosts; } \\
\text { b) Starlight Reef, Great Bear Reef, Cormorant Rocks near } \\
\text { Cleland Island and other important low boat traffic sites for } \\
\text { Brandt's Cormorants }\end{array}$ \\
\hline $\begin{array}{l}\text { Set-back distance } \\
\text { (some High boat } \\
\text { traffic sites where } \\
\text { habituation has } \\
\text { occurred) }\end{array}$ & $\begin{array}{l}\text { On some nest and roost sites seabird exhibited little reaction to boats } \\
\text { at distances under } 30 \mathrm{~m} \text {. Managers can use discretion with set-back } \\
\text { distances between } 30 \text { and } 50 \mathrm{~m} \text { to allow viewers to observe sea-birds } \\
\text { at close range; }\end{array}$ \\
\hline Approach speed & Slow the boat to less than $5 \mathrm{~km} / \mathrm{hr}$ at $200 \mathrm{~m}$; \\
\hline Approach angle & $\begin{array}{l}\text { Approach birds at a low tangential angle rather than directly, then } \\
\text { move along parallel to shore. Avoid startling birds by not } \\
\text { 'sneaking' around corners of rocks or islets. This applies } \\
\text { particularly to kayakers who tend to travel close to the shore; }\end{array}$ \\
\hline Approach & $\begin{array}{l}\text { Monitor behavior of birds. Watch for head raising, alertness, } \\
\text { calling, shuffling of feet or walking. Increase angle away from birds } \\
\text { if they become agitated; }\end{array}$ \\
\hline Leaving & $\begin{array}{l}\text { Move away slowly from the animals when leaving an area and then } \\
\text { gradually increase speed }\end{array}$ \\
\hline
\end{tabular}




\section{Implementation of seabird viewing guidelines}

Effective implementation of guidelines can be achieved through a variety of management techniques which include establishing codes of conduct or practice in consultation with boat tour operators, park and management agencies, marking of set-backs, permits and training, wardening, and education. These methods are discussed below.

\section{Codes of conduct or practice}

Codes of conduct are voluntary procedures and rules for visiting seabird colonies that are developed through consultation with the users (tour operators), management agencies and research organizations (Great Barrier Reef Marine Park Authority, 1997). The advantage of this process is that tour operators become educated in the value of conservation of seabirds and then have a sense of ownership and stewardship for the birds and habitat. These codes are selfregulating as operators tend watch each other to ensure adherence to guidelines. Codes of conduct cannot govern casual recreationists.

\section{Set-back marking}

Burger et al. (2010) recommended marking the set-back buffer at any sensitive site with an offshore buoy placed at the beginning of the breeding season. A few strategically placed buoys would help visitors and boat-drivers to gauge the $50 \mathrm{~m}$ buffer and allow them to apply this buffer more widely at all sites, marked or not. This method of marking is comparable to designating trails or viewing points and is a way of leading both casual visitors and tour operators away from sensitive areas. 


\section{Permits and Training}

Tour-operators require permits to operate within Provincial Parks, Ecological Reserves and National Parks. Guidelines and expected conduct for viewing seabirds can be written into permit conditions. The Great Barrier Reef Authority of Australia (1997) recommends an accreditation scheme for guides which include training. Training can be simple and include a module developed for guides regarding wildlife and procedures. Videos can be useful for training purposes.

\section{Wardening}

Wardening involves the presence of a ranger or authorized volunteer at the approach to an active seabird colony. Regular wardening has resulted in improved surface nesting seabird breeding success in Australia (Newsome et al., 2002) and the volunteer wardens at Mitlenatch Island in the Strait of Georgia have prevented much disturbance of this important seabird colony ( personal observation). Langston et al. (2007) found that personal wardening was more effective for implementing restrictions than signs on countryside right-of-ways in Britain. The volunteer Ecological Reserve Wardens for Great Chain Island and Cleland Island Ecological Reserves provide additional presence to assist seasonal Park Rangers in their duties.

\section{Education}

Guidelines, including set-back buffers must be supported by effective communication of the rationale and scientific justification for guidelines and the value of protecting seabirds. Much of the disturbance damage to seabirds is done unknowingly and without intent. Education and interpretation are important in increasing public awareness of the significance of breeding 
seabirds, their vulnerability to human disturbance and conveying the codes of conduct for visitors. Education is effective in reducing impacts of visitors and addressing careless, uninformed actions that harm wildlife (Newsome et al., 2002) and can be used to guide visitors to designated or selected locations (Rollins et al., 2009) including areas outside set-backs buffers. Hvenegaard et al. (2009) discuss the values of effective interpretation which include filling visitors with a sense of wonder and curiosity about nature, providing visitors with opportunity to act on a new sense of respect, benefiting the ecological integrity of national parks and surrounding environments. Sharpe (1982) notes that one of the main benefits of park interpretation programs is "to motivate the public to take action to protect their environment". In a study of the effect of tour boats on flamingos in the Yucatan, Mexico, Galicia and Baldassare (1997) recommended education of tourists who could then act as enforcement agents to the tourboat operators.

Brochures, signs, articles in kayak and local tourist magazines play a role in informing visitors about the natural history of seabirds, their vulnerability and the set-back distances. Signage should be concise and appropriately located near boat launch areas, marinas and landbased parks. Brochures similar to the "Seabird Survival Program" or the "Be Whale Wise: Guideline for Watching Marine Wildlife" (Fisheries and Oceans Canada, 2007) can be distributed via tour group operators, ranger patrols, boat launching areas and at local angling, boating and sailing clubs. Articles in popular recreational and fishing magazines (such as Wavelength, British Columbia and BC Outdoors) are important ways of communicating guidelines to individual boaters. 


\section{Conclusions}

There are many factors that affect seabird disturbance by boats. To fully identify the importance of each factor would require a large sample with careful attention to balancing variables. The trends shown by this study demonstrate that bird species, habituation to boat traffic, nesting and boat type were the most important factors affecting the distance at which surface-nesting seabirds responded to boats off Vancouver Island. Seasonality was less important. At $40 \mathrm{~m}$ away from surface-nesting seabirds on Vancouver Island there was, on average, less than $10 \%$ probability of an agitation response. Roosting seabirds were more sensitive and Harlequin Ducks in particular had $25 \%$ probability of an agitation response at distances less than $50 \mathrm{~m}$. Sites with less than 1 boat passing per day (Low boat traffic) during the breeding season had higher probabilities of birds being agitated at all distances.

A set-back guideline of $50 \mathrm{~m}$ would protect most seabird sites on Vancouver Island and particularly in the Salish Sea. However, certain roost sites for aggregating Harlequin Ducks and Brandt's Cormorants as well as remote nest sites with Low boat traffic on the west coast of Vancouver Island would be better protected by a $70 \mathrm{~m}$ set-back distance. These set-back guidelines determined by experimentation are significantly less than the $100 \mathrm{~m}$ guidelines recommended at present. The shorter distance will allow viewers to appreciate seabirds and encourage better compliance. Education, permitting requirements, marker buoys and wardening are methods recommended to promote adherence to the guidelines. 


\section{References}

Amato, C. (1995). A sense of balance: Working towards a new wildlife ethic for kayakers. Sea Kayaker, December 1995, 37-40.

Anderson, D. W., \& Keith, J. O. (1980). The human influence on seabird nesting success: Conservation implications. Biological Conservation, 18, 65-80.

Anonymous. (2008). Brandt's Cormorant (Phalacrocorax penicillatus). Alaska Seabird Information Series Retrieved January 17, 2010, from http://alaska.fws.gov/mbsp/mbm/seabirds/pdf/brco.pdf

B.C. Conservation Data Centre. (2010). Species Summary: Histrionicus histrionicus, Species Summary: Phalacrocorax penicillatus, Species Summary: Phalacrocorax auritus (Publication. Retrieved January 5, 2010, from BC Ministry of Environment: http://a100.gov.bc.ca/pub/eswp

Beale, C. M. (2007). Managing visitor access to seabird colonies: a spatial simulation and empirical observations. Ibis, 149, 102-111.

Bellefleur, D., Lee, P., \& Ronconi, R. A. (2009). The impact of recreational boat traffic on Marbled Murrelets (Brachyramphus marmoratus). Journal of Environmental Management, 90, 531-538.

Blumstein, D. T., Harcourt, A. R., \& Ross, G. (2003). Testing a key assumption of wildlife buffer zones: is flight initiation distance a species-specific trait? Biological Conservation, $110,97-100$. 
Burger, J. (1981). Effects of human disturbance on colonial species, particularly gulls. Colonial Waterbirds, 4, 28-36.

Burger, J., \& Gochfeld, M. (1981). Discrimination of the threat of direct versus tangential to the nest by incubating herring and great black-backed gulls. Journal of Comparative Physiology and Psychology, 95, 676-684.

Burger, J., \& Gochfeld, M. (1993). Tourism and short-term behavioural responses of nesting Masked, Red-footed and Blue-footed Boobies in the Galapagos. Environmental Conservation, 20, 255-259.

Burger, J., Gochfeld, M., Jenkins, C. D., \& Lesser, F. (2010). Effect of approaching boats on nesting Black Skimmers: Using response distances to establish protective buffer zones. Journal of Wildlife Management, 74, 102-108.

Burger, J., Gochfeld, M., \& Niles, M. J. (1995). Ecotourism and birds in coastal New Jersey: Contrasting responses of birds, tourists and managers. Environmental Conservation, 22, 56-65.

Cairns, D. K., Dibblee, R. L., \& Daoust, P. V. (1998). Displacement of a large double-crested cormorant colony following human disturbance. The Canadian Field Naturalist, 520-522.

Campbell, R. W., Dawe, N. K., McTaggart Cowan, I., Cooper, J. M., Kaiser, G. W., \& McNall, M. C. E. (1990). Birds of British Columbia (Vol. 1: Non-Passerines; Introduction, Loons through Waterfowl). Victoria, British Columbia: Royal BC Museum. 
Canadian Wildlife Service Technical Committee. (2003). Guidelines for visiting seabird colonies in Canada. Ottawa: Canadian Wildlife Service.

Carney, K. M., \& Sydeman, W. J. (1999). A review of human disturbance effects on nesting colonial waterbirds. Waterbirds, 22, 68-79.

Chatwin, T. A., Mather, M. H., \& Giesbrecht, T. D. (2002). Changes in Pelagic and DoubleCrested Cormorant nesting populations in the Strait of Georgia, British Columbia Northwestern Naturalist, 83, 109-117.

Erwin, R. M. (1989). Responses to human Intruders by birds nesting in colonies: Experimental results and management guidelines. Colonial Waterbirds, 12, 104-108.

Fetherston, D. (Cartographer). (2010). Study areas on Vancouver Island showing major nest and roost sites. [ArcGIS Software, Version 9. 2004].

Fisheries and Oceans Canada. (2007). Be Whale Wise: Guidelines for Watching Marine Wildlife (Pamphlet). Ottawa: Government of Canada.

Fowler, G. S. (1999). Behavioral and hormonal responses of Magellanic penguins (Spheniscus magellanicus) to tourism and nest site visitation. Biological Conservation, 90, 143-149.

Frid, A., \& Dill, L. M. (2002). Human-caused disturbance stimuli as a form of predation risk [Electronic Version]. Conservation Ecology, 6. Retrieved November 21, 2008 from http://www.ecologyandsociety.org/vol6/iss 1/art11/main.html. 
Galicia, E., \& Baldassarre, G. (1997). Effects of motorized tourboats on the behaviour of nonbreeding American flamingos in Yucatan, Mexico. Conservation Biology, 11, 11591165.

Gaston, A. J. (2004). Seabirds:A natural history. New Haven, Connecticut: Yale University Press.

Giesbrecht, T. D. (2001). The Effect of Bald Eagles and Boat Traffic on Nesting Double-crested Cormorants (Phalacrocorax auritus) in the Strait of Georgia. Unpublished Report. Nanaimo, BC: BC Ministry of Environment, Lands and Parks.

Gill, J. A. (2007). Approaches to measuring the effects of human disturbance on birds. Ibis, 149, 9-14.

Goudie, R. I., \& Ankney, C. D. (1986). Body size, activity budgets, and diets of sea ducks wintering in Newfoundland. Ecology, 67, 1475-1482.

Gray, P. A., Duwors, E., Villeneuve, M., Boyd, S., \& Legg, D. (2003). The socioeconomic significance of nature-based recreation in Canada. Environmental Monitoring \& Assessment, 86, 129-147.

Great Barrier Reef Marine Park Authority. (1997). Guidelines for Visitation to Seabird Breeding Islands. Retrieved. from http://www.gbrmpa.gov.au/_data/assets/pdf_file/0019/4465/seabirds1.pdf.

Harrington, D. (2005). Linear Rank Tests in Survival Analysis Standard Article. In Encyclopedia of Biostatistics. Toronto: Wiley, Interscience. 
Hentze, N. (2006). The Effects of Boat Disturbance on Seabirds off Southwestern Vancouver Island, British Columbia. Unpublished BSc Honours, University of Victoria, Victoria, $\mathrm{BC}$.

Hill, D., Hockin, D., Price, D., Tucker, G., Morris, R., \& Treweek, J. (1997). Bird disturbance: Improving the quality and utility of disturbance research. The Journal of Applied Ecology, 34, 275-288.

Hockin, D., Ounsted, M., Gorman, M., Keller, V., \& Barker, M. A. (1992). Examination of the effects of disturbance on birds with reference to its importance in ecological assessments. Journal of Environmental Management, 36, 253-286.

Holmes, N., Giese, M., \& Kriwoken, L. K. (2005). Testing the minimum approach distance guidelines for incubating Royal penguins (Eudyptes schlegeli). Biological Conservation, 126, 339-350.

Hvenegaard, G. T., Shultis, J., \& Butler, J. R. (2009). The role of interpretation. In P. Dearden \& R. Rollins (Eds.), Parks and protected areas in Canada: Planning and management (pp. 202 - 236). Don Mills, Ontario: Oxford University Press.

Important Bird Areas of Canada, \& Federation of BC Naturalists. (2006). The Seabird Survival Program: How you can make a Difference (Brochure). Vancouver, BC: Federation of BC Naturalists.

Langston, R. H. W., Drewitt, A. L., \& Liley, D. (2007). Bird conservation and access: coexistence or compromise? British Wildlife, 19, 1-9. 
Lawless, J. F. (2002). Statistical Models for Lifetime Data (2nd ed.). Toronto: Wiley.

Leonard, J. (2006). Wildlife watching in the U.S.: The economic Impacts on National and state economies in 2006.Addendum to the 2006 National survey of fishing, hunting, and wildlife-associated recreation. Retrieved November 21, 2008. from http://library.fws.gov/nat_survey2006_economics.pdf.

Manuwal, D. A. (1978). Effect of man on marine birds; a review. In M. Kirkpatrick (Ed.), Wildlife and people (pp. 140-160). West Lafayette, Indiana: Purdue Research Association.

Montgomerie, R. D., \& Weatherhead, P. J. (1988). Risks and Rewards of Nest Defence by Parent Birds. The Quarterly Review of Biology, 63(2), 167-187.

Moul, I. E., \& Gebauer, M. E. (2002). Status of the Double-crested Cormorant in British Columbia (Wildlife Working Report No. WR-105). Victoria, BC: Province of BC.

Murphy, P. E. (1994). Tourism and sustainable development. In W. Theobald (Ed.), Global tourism: The next decade (pp. 274 - 290). Oxford, U.K.: Butterworth-Heinemann.

Newsome, D., Moore, S. A., \& Dowling, R. K. (2002). Natural areas tourism: Ecology, impacts and management (Vol. 4). North York, Ontario: Channel View Publications.

Nisbet, I. C. T. (2000). Disturbance, habituation, and management of waterbird colonies. Waterbirds, 23, 312-332. 
Parks Canada. (2003). Pacific Rim National Park Reserve:Seabird and shoreline viewing guidelines: Site Specific Viewing Guidllines Final 2003. Ucluelet, BC: Government of Canada.

Parks Canada. (2006). Gulf Islands National Park Reserve of Canada: Interim management guidelines. Government of Canada: Sidney, BC.

Peek, J. A., Pelton, M. A., Picton, H. D., Schoen, J. W., \& Zager, P. (1987). Grizzly Bear conservation and management: A review. Wildlife Society Bulletin, 15, 160-169.

R Development Core Team. (2008). R: A language and environment for statistical computing. Retrieved July 30, 2008, from http://www.R.project-org

Regal, J., \& Putz, K. (1997). Effect of human disturbance on body temperature and energy expenditure in penguins. Polar Biology, 18, 246-253.

Rodgers, J., \& Schwikert, S. (2002). Buffer-zone distances to protect foraging and loafing waterbirds from disturbance by personal watercraft and outboard-powered boats. Conservation Biology, 16, 216-224.

Rodgers, J., \& Smith, H. T. (1995). Set-back distances to protect nesting bird colonies from human disturbance in Florida. Conservation Biology, 9, 89-99.

Rodway, R. S., Regehr, H. M., \& Cooke, F. (2003). Sex and age differences in distribution, abundance, and habitat preferences of wintering Harlequin Ducks: implications for conservation and estimating recruitment. Canadian Journal of Zoology, 81, 492-503. 
Roe, D., Leader-Williams, N., \& Dalal-Clayton, B. (1997). Take only photographs, leave only footprints: The environmental impacts of wildlife tourism. London, U.K.: International Institute of Environment and Development.

Rollins, R., Eagles, P., \& Dearden, P. (2009). Tourism, ecotourism and protected areas. In P. Dearden \& R. Rollins (Eds.), Parks and protected areas in Canada: planning and management (pp. 314 - 341). Don Mills, Ontario: Oxford University Press.

Ronconi, R. A., \& Cassady St. Clair, C. (2002). Management options to reduce boat disturbance on foraging black guillemots (Cepphus grylle) in the Bay of Fundy. Biological Conservation, 108, 265-271.

Sharma, A. (2005). Kaplan-Meier. isixsigma.com/dictionary Retrieved January 12, 2010, from http://www.isixsigma.com/dictionary/Kaplan-Meier-780.htm

Sharpe, G. W. (1982). Interpreting the Environment (2nd ed.). New York: John Wiley and Sons.

Sutherland, W. J. (2007). Future directions in disturbance research. Ibis, 149, 120-124.

Tarlow, E. M., \& Blumstein, D. T. (2007). Evaluating methods to quantify anthropogenic stressors on wild animals. Applied Animal Behaviour Science, 102, 429-451.

Tisdell, C., \& Wilson, C. (2000). Wildlife-based tourism and increased tourist support for nature conservation financially and otherwise: Evidence from sea turtle ecotourism at Mon Repos (Working paper No. 54). Queensland: University of Queensland. 
Tisdell, C., \& Wilson, C. (2006). Information, Wildlife Valuation, Conservation: Experiments and Policy. Contemporary Economic Policy, 24(1), 144-159.

Vennesland, R. G. (2010). Risk perception of nesting Great Blue Herons: Experimental evidence of habituation. Canadian Journal of Zoology, 88, 81-89.

Vennesland, R. G., \& Butler, R. W. (2004). Factors influencing Great Blue Heron nesting productivity on the Pacific coast of Canada from1988 to1999. Waterbirds, 27, 289-296.

Vermeer, K., \& Rankin, L. (1994). Population trends in nesting Double-crested and Pelagic Cormorants in Canada. Murrelet, 65, 1-9.

Walker, B. G., Boersma, P. D., \& Wingfield, J. C. (2006). Habituation of adult Magellanic Penguins to human visitation as expressed through behaviour and corticosterone secretion. Conservation Biology, 20(1), 146-154.

Weimerskirch, H., Shaffer, S. A., Mabille, G., Martin, J., Boutard, O., \& Rouanet, L. (2002). Heart rate and energy expenditure of incubating wandering albatrosses: basal levels, natural variation, and the effects of human disturbance. Journal of Experimental Biology, 205, 475-483.

Wilson, R. P., Culik, B. M., \& Adelung, D. (1991). People in Antarctica - how much do Adelie Penguins (Pygoscelis adeliae) care? Polar Biology, 11, 363-370. 


\section{Appendix 1 Data Collection Form}

\section{SEABTRD DISTURBANCE}

Date Tu/y 10, 2009

Overall Location

Mitlenateh Island

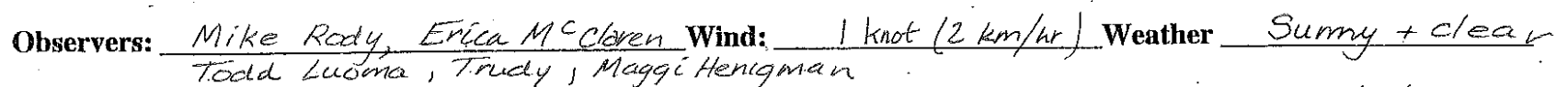

Sea-conditions swell height:

Boat traffic (high; medium, low _ High

\begin{tabular}{|c|c|c|c|c|c|c|c|c|c|c|c|}
\hline $\begin{array}{l}\text { Locality and Boat } \\
\text { Type Kayák (K) or } \\
\text { Motorboat (B) }\end{array}$ & $\begin{array}{l}\text { Roost } \\
\text { or } \\
\text { Nest }\end{array}$ & Species & Number & $\begin{array}{l}\text { Distance } \\
\text { test } \\
\text { started }\end{array}$ & $\begin{array}{c}\text { Distances } \\
.\end{array}$ & $\begin{array}{l}\text { Distance } \\
\text { agitated }\end{array}$ & $\begin{array}{l}\text { Distance to } \\
1^{\text {st }} \text { Flight }\end{array}$ & $\begin{array}{l}\text { How } \\
\text { many } \\
\text { flew? }\end{array}$ & $\begin{array}{l}\text { Distance to } \\
\text { greatest } \\
\text { disturbance } \\
\text { or test end } \\
\end{array}$ & $\begin{array}{l}\text { No of } \\
\text { birds } \\
\text { flew }\end{array}$ & Comments \\
\hline Motorbogt & Roost & PECO & 10 & 214 & $\begin{array}{l}185,156,1 / 2 \\
87,75,6546\end{array}$ & 26 & - & $\ldots$ & 23 & & $\begin{array}{l}\text { Rocks between } \\
\text { bout t-birds }\end{array}$ \\
\hline & Nest & PECO & 5 & 214 & 1,1 & - & - & $-\cdots$ & 23 & . & No disturbat \\
\hline .1 & Roost & $\Delta c c 0$ & 4 & 214 & 11 & 26 & - & - & 23 & & $\begin{array}{l}\text { Rocks bethuen } \\
\text { boar + binds }\end{array}$ \\
\hline & Roost & PEEO & 12 & 214 & 11 & 19 & 12 & 11 & 12 & & \\
\hline Motor boat & Nest & PECO & 16 & 161 & $\begin{array}{l}93,65,48 \\
35,17\end{array}$ & - & - & - & 17 & & No disturbance \\
\hline & Roost & $\triangle C C O$ & 4 & 161 & 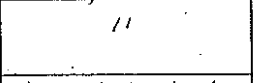 & - & - & - & 17 & & No disturtarce \\
\hline Motor boat & Nest & GNGU & 9 & 215 & $\begin{array}{l}168,135,106 \\
84,51,51,29 \\
\end{array}$ & r & $-\cdots$ & $\therefore$ & 29 & & $\begin{array}{l}\text { No idisturtanke } \\
\text { caredn'tyet closen }\end{array}$ \\
\hline & R/Nest & PlGU & 6 & 215 & 11 & - & - & - & 29 & & 118 \\
\hline & $R$ & BLOY & 2 & $215^{\circ}$ & 35,22 & - & $\ldots$ & - & 22 & & No distunian \\
\hline Motorbot & $N+R$ & GWGL & 14 & 90 & $\begin{array}{l}52,46,15,27 \\
2,\end{array}$ & $\begin{array}{l}\text { 1.Roostimy } \\
\text { Agituted /7 }\end{array}$ & & & $1 \%$ & & $\begin{array}{l}1 \text { disturbeg } \\
\text { othese } O K<\end{array}$ \\
\hline SNotorlest & $N+R$ & GUGU & 10 & 183 & $\begin{array}{l}133,107,79,5 ! \\
45,22\end{array}$ & - & - & - & 17 & & $\begin{array}{l}\text { Eults not } \\
\text { disturbed }\end{array}$ \\
\hline & そ & $2 x<C O$ & 4 & "t & $\begin{array}{c}133,107,79,5 i \\
45,22\end{array}$ & 45 & $\begin{array}{l}45- \\
22 \\
\end{array}$ & $\begin{array}{l}1 \\
3\end{array}$ & 17 & & $\begin{array}{l}\text { Most DCCO } \\
\text { not disturbed }\end{array}$ \\
\hline$\because$ & 12 & BLOY & 2 & 183 & $1 /:$ & $\cdots$ & $\ldots$ & - & - & & Not distuben \\
\hline
\end{tabular}

